\title{
Studying the Effect of Stakeholders on the Disclosure of Corporate Social Responsibility by Banks: Evidence from Egypt
}

\author{
Engy ElHawary ${ }^{1} \&$ Iman M. Arafa $^{2}$ \\ ${ }^{1}$ Accounting and Finance Department, Faculty of Business, Eonomics and Political Science, British University in \\ Egypt (BUE), Cairo, Egypt. \\ ${ }^{2}$ Accounting Department, Faculty of Commerce, Cairo University, Giza, Egypt. \\ Correspondence: Engy ElHawary, Faculty of Business, Eonomics and Political Science, British University in Egypt \\ (BUE), Cairo, Egypt. Tel: 02-20-122-341-6833. E-mail: engy.elhawary@ bue.edu.eg.
}

Received: October 29, 2018

doi:10.5430/afr.v7n4p200
Accepted: November 22, $2018 \quad$ Online Published: November 23, 2018

URL: https://doi.org/10.5430/afr.v7n4p200

\begin{abstract}
Stakeholders have become more attentive to community and social information worldwide. However, their influence on the CSR disclosure is highly contextual and contingent upon several institutional factors. Therefore, this study pursues to identify the stakeholders' group which has the most powerful effect on the CSR disclosure. The researchers examined the CSR disclosure provided by 38 banks operating in Egypt for the year 2015. Two main indices have been developed; one measures the extent of the CSR disclosure and denoted as as the CSR quantitative index. The other measures the qualitative aspects and denoted as the CSR qualitative index. In addition, five sub-indices have been developed to measure the CSR disclosure as recommened by the GRI. The relationship between these two main indices and the sub-indices and the seven groups of stakeholders have been examined using the OLS regression models. The non-parametric tests are also used to enhance the robustness of our findings and to identify the differences between the stakeholders for each index. Concerning the stakeholder effect, the Egyptian Stock exchange, audit committee and big audit firms are found to have the most powerful impact in our case. On contrary, independent directors, bank's clients and bank specialty show insignificant results. Generally, the quality and extent of CSR disclosure by the banking sector still undeveloped, particularly for the national banks. Accordingly, the Egyptian Stock Exchange and the Central bank of Egypt need to issue vigorous guidelines and regulations to raise harmonization in the CSR disclosure and to empower their supervisory role in this respect.
\end{abstract}

Keywords: corporate social responsibility, stakeholder theory, corporate governance, audit committee, Egyptian stock exchange, legitimacy theory

\section{Introduction}

\subsection{Introduce the Problem}

A growing interest in social and environmental activities has been extensively spreading in the last two decades among countries. Many companies have become more involved in mutual social contract with their communities and stakeholders. Basically, the social and environmental role has become a key part of many companies' strategies, specifically in the developed economies. In effect, different professional and regulative bodies have recently stimulated companies to enhance their disclosures concerning social and environmental activities to the public. Such social and environmental activities are commonly known as corporate social responsibility (Hereafter CSR). Since the last century, increasing efforts have been undertaken to incorporate the CSR with financial and trading activities.

Accordingly, the CSR disclosure is no more considered as a chief factor influencing the reputation of firm only, but also it has become a considerable part of their policies and strategies and required by its stakeholders. In addition, the quality of CSR disclosure is highly required by them with sufficient quantity. Stakeholders' support is essential for running any business. The quality of the information is important to enable stakeholders to make sound and reasonable assessments of performance, and take appropriate actions (G4, GRI 2014). That is why their influence and pressure on the CSR disclosure both quantity and quality is under the study. Hasseldine et al. (2005) stated that studying the quantity of disclosure alone will give the wrong conclusions. Therefore, it is important to know whether the influence of the stakeholders will improve the quality of information in the sustainability report as well as the quantity. Rudyanto and Siregar (2018) examined the effects of stakeholder pressure and corporate governance on the 
quality of sustainability report as it was vital to win the negotiation process with stakeholders.

The CSR practices in the developing countries are still immature and needs more efforts to be integrated into the firm's activities (Alotaibi \& Hussainey, 2016a). In such countries, the awareness of the CSR importance to the organization sustainability and performance is not only missing, but also the mechanisms to impose these activities are not legitimately developed yet. Moreover, role of stakeholders in the CSR disclosure is unrecognized and relatively limited. Accordingly, the purpose of this study is to identify the powerful set of stakeholders who dominate the CSR disclosure in the Egyptian banking sector. This sector is selected as it plays a crucial role in social and economic development of any country. The researchers collected the CSR data using the content analysis method and developed CSR indices which has been fully described in our previous paper (Arafa \& ElHawary, 2017). The stakeholder's data have been collected from different sources namely; Thomson Reuter's database, Bank Scope, and companies' websites. The empirical study investigated the impact of different stakeholders using both parametric and non-parametric analysis. To develop more comprehensive view regarding the current CSR disclosure, the researchers considered the entire population of the banks operating in Egypt during 2015 and they per se constitute part of the financial sector in Egypt.

The empirical results revealed a significant positive impact of the listing status in the Egyptian Stock Exchange (hereafter EGX), auditors' firm type and audit committee on some quantitative indices. However, it has been shown that bank exposure (i.e. clients' effect) has an insignificant impact on both the extent and quality of the CSR disclosure. Though audit committee has a significant impact on several indices, the independent directors' impact was insignificant in many cases. The non-parametric results were consistent with our regression results and both elaborated that foreign, non-governmental and listed banks on EGX have attained higher level of CSR disclosure, yet at a moderate quality level. Though the extent and quality of CSR disclosure for foreign banks were evidently higher than those of the national banks, they were not up to the level attained in their home countries. This indicates that the institutional environment in Egypt is still underdeveloped and thus has a poor influence on the CSR disclosure by non-Egyptian banks. These findings also emphasize the importance of empowering the supervisory role of the Egyptian Stock Exchange and the Central bank of Egypt to raise the quality and quantity levels of the CSR disclosure in the banking sector.

This paper proceeds as follows. Section 1 represents the theoretical background by discussing the CSR disclosure through the lances of several related theories including stakeholder and legitimacy theories. This section also reviews the CSR related literature while elaborating the different hypotheses that have been developed based on the stakeholder theory. Section 2 discuss the stakeholders' theory in relation to the CSR context. Section 3 elaborates the pertinent literature and the proposed hypotheses. Section 4 shows the research methodology including the selected population and the main characteristics of the constituents. The definitions, codes and measures of the dependent, independent and control variables have been illustrated in this section as well as the regression models have been also included in this section. The empirical results are exhibited in Section 5, meanwhile Section 6 discusses the results, conclusions, and provides suggestions for future research.

\subsection{The Importance of the Problem}

This paper has important implications for academia as well as the regulative and banks' management in Egypt. Our findings have also emphasized the need to improve the legislative environment and the existing regulations concerning the CSR disclosure for surging the harmonization across banks and raising the potential benefits to different groups of stakeholders. The results of this study are subject to some limitations which are the limited size of the investigated population, the narrow time horizon (one year) and relative subjectivity of the content analysis method.

This paper contributes to the CSR literature in emerging economies by shedding light on different types of stakeholders, especially bank's clients, peers and stock exchange which have been regularly overlooked in the developing countries. It has also considered the impact of stakeholders on the qualitative aspects of CSR disclosure as an incremental feature complementing the quantitative ones. Additionally, the entire population including both foreign and national banks have been examined to construct a comprehensive view of the contemporary CSR practices in Egypt.

\section{Research Background: The CSR Disclosure and Stakeholders Theory.}

An abundant research on the CSR disclosure by companies has been extensively conducted embracing different theoretical perspectives. Rudyanto and Siregar (2018) have focused on the ethical side inherent in sustainability to examine the pressure of stakeholders on CSR quality. They mentioned that many ethical theories used by some 
authors (e.g. Phillips et al., 2003; Robinson, 2004) to describe moral in sustainability. Many papers (e.g. Zsolnai, 2011; Rajalakshmi, 2016) use environmental ethics as basis of sustainability ethics. On the hand, the economy side of sustainability ethics can be defined by the agency theory.

The agency theory suggests that firms may use a compensation plan or provide voluntary disclosure to reduce the agency costs. As a result, firms are expected to be more accountable to its stakeholders and to the whole society. To this end, companies incorporate social information in their annual reports to enhance the firm's reputation in its stakeholders' eyes and to satisfy the community's need (Hassan \& Marston, 2010). For instance, it has been found that stakeholders (i.e. NGOs) have wielded a great pressure on the mining companies to act in favor of the society by employing five main mechanisms; demands, communication, counselling, control and engagement (Viveros, 2017). In the same vein, El Kayaly (2014) investigated the CSR disclosure in Egypt and found that it has been used primarily as a marketing or public relation tool. This argument highlights and leads us to the following group of theories.

The legitimacy and institutional theories are interrelated and commonly used while interpreting the CSR disclosure in different institutional contexts (Deegan, 2002; Andrikopoulos et al., 2014, De Villiers \& Alexander, 2014; Bonsón \& Bednárová, 2015; Ortas et al. 2015; and Preuss et al., 2016). De Villiers and Alexander (2014) argues that banks can legitimize its existence and earn social approval by disclosing their CSR activities to different stakeholders. To be legitimate, companies including banks would strive to provide information that affect their stakeholders and society's perception about the company (Yeh et al., 2011). As the increasing demand for the CSR disclosure has been driven by the popularity of stakeholders, the stakeholder theory has become the dominant foundation for most of CSR research and thus constitutes a crucial part of the socio-organizational approach. This theory has been originally developed by Freeman (1984) who defined stakeholders as "any group of individuals that can affect or is affected by the achievement of business objectives" (Moir, 2001). To satisfy the different needs of stakeholders, companies may opt to report on the broader economic, social and environmental aspects whether in their annual reports or in a standalone report (i.e. Sustainability Report). Thus, the CSR disclosure is perceived as a communication means to convince the stakeholders that the bank or the firm is meeting their expectations (Branco \& Rodrigues, 2008).

Briefly, it can be argued that various groups of stakeholders normally require different types of information as illustrated in Figure 1. These stakeholders may cause a direct or indirect effect on the CSR disclosure in terms of the quantitative aspect "How much is disclosed?" or the qualitative aspects "How good the disclosure is?". Hence, we expect that the influence of the most powerful stakeholders is the one that dictates the legitimate feature of the CSR disclosure.

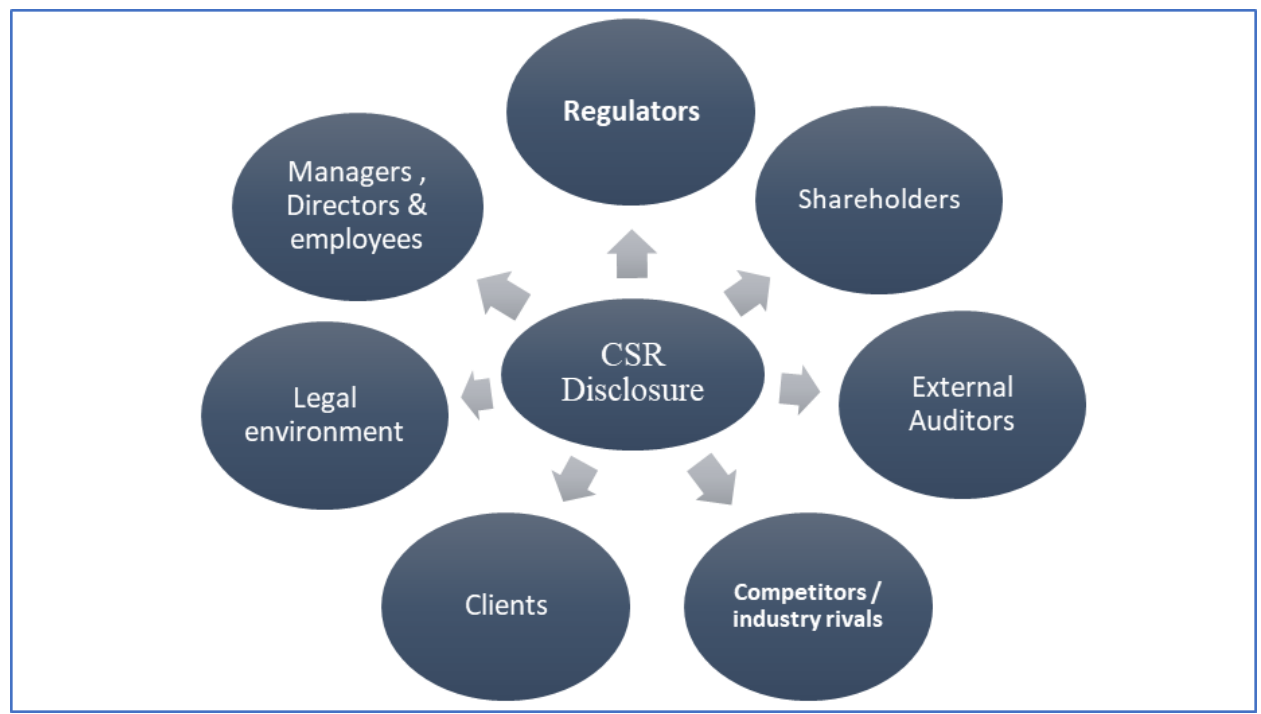

Figure 1. The potential stakeholders' influencing the CSR

Some researchers have commonly execluded the banking sector while studying the CSR disclosure of companies as they belong to a regulated industry (see, for example: Cormier \& Gordon, 2001; Haniffa \& Cooke, 2005; Beck et al. 2010; and Cormier et al., 2011). Others have examined the CSR disclosure in total while ignoring the unique differences among them (e.g. Tsang, 1998; Sobhani et al., 2009; Bouten et al., 2011; and Lock \& Seele, 2015). Other researchers like Özçelik and Öztürk (2014) and Ghabayen et al. (2016) believe that the banking sector constitutesa 
key pillar in the economic and financial system as it has significant economic and scoial influence on the overall development process in any country. This is one of the reasons that have motivated the researchers to focus on this sector.

Developing countries in general and Arabic countries in specific have scarcity of studies related to CSR disclosure. In addition, the financial sector has been widely ignored in previous literature due to their rigorous regulatory system (Barako \& Brown, 2008). The researchers (e.g. Joseph, 2008; Dhouibi \& Mamoghli, 2013; Rahman \& Iqbal, 2013; Özçelik \& Avci Öztürk, 2014; Chakroun \& Mbirki, 2015; Krasodomska, 2015 and Alotaibi \& Hussainey, 2016b) investigated the banking sector in other developing countries by measuring the CSR disclosure level and identifying the key factors affecting the low CSR disclosure level found in such countries.

\section{Literature Review and Hypotheses Development}

Our study attempts to answer a key research question: who is/are the most powerful group that drives the CSR disclosure in the banking sector? Egypt is considered as a country in transition which has paid a great attention to the CSR disclosure in the recent years and thus selected to be the context of this study. The potential stakeholders will be classified, in terms of their relationship with the bank, into two main groups. The external stakeholders group who exists outside the bank premises but may have indirect effect on the business strategies such as stock market, peers, external auditors in addition to the existing clients. Meanwhile, internal stakeholders exist inside the bank and participate directly in setting the business strategies such as independent directors and audit committee. From a broader view, shareholders will be considered as a part of the internal stakeholders as they have very close relationship with the bank. Other internal stakeholders such as employees may have also important effect on the CSR disclosure. The above argument is supported by similar studies which suggest that pressures from powerful stakeholders, rather than efficiency incentives, are the drivers for the CSR disclosures (Metaxas \& Tsavdaridou, 2010, Ullah \& Rahman, 2015, Yu \& Choi, 2016, and Viveros, 2017). The subsequent paragraphs illustrate the hypotheses that test the relationship between the CSR quantitative and qualitative aspects and eight different groups of stakeholders.

\subsection{The Stock Market Effect}

According to the agency theory, the CSR activities may help companies retain superior profits and reduce the agency conflict between management and its shareholders (Nan et al., 2010, Alotaibi \& Hussainey, 2016b). This theory is consistent with signaling theory which suggests that mangers are more likely to disclose information that signal their favorable results to their shareholders (Hassanein \& Hussainey, 2015). Hence, participating in the CSR activities is expected to enable companies to establish a good reputation in the capital markets (El Kayaly, 2014; and Alotaibi \& Hussainey, 2016a). Sul et al. (2014) argue that signaling and institution-based view can jointly contribute to the CSR literature. They elaborate, in emerging economies, firms that adopt CSR practices positively signal investors that their firms have superior capabilities for filling institutional voids.

Non-financial reporting regulations, governments and stock markets play a key role in promoting CSR disclosure (Bonsón \& Bednárová, 2015). Branco and Rodrigues (2006) suggest that listed banks are considered to be more visible than its counterparts as they normally receive more attention from the general public and are subject to more extensive media coverage. In the same vein, (Boubakri et al., 2016) find that cross-listing is positively associated with CSR performance whereas foreign firms listed on U.S. stock exchange. This relation holds true for two types of CSR disclosures; environmental and social disclosures. It is also argued that banks listed on the stock exchange are obliged to comply with regulations and guidelines related to information disclosure (Hu \& Scholtens, 2014). This may induce them to follow more professional pattern while disclosing their social and environmental information. For instance, Fernandez-Feijoo et al. (2014) studied and classified the corporate CSR practices into four possible types of behavior; Novice, Cautious, Chattering and Leading. They reported that companies listed in the stock market disclose more CSR information than private ones but with less credibility. It is also concluded that European countries are the leaders in respect of CSR disclosure and tend to have a Cautious or Leading attitude. (Fernandez-Feijoo et al., 2014). On the contrary, Hu and Scholtens (2014) studied the CSR in 44 developing countries and found no significant relationship between either being listed or the number of shareholders and the CSR disclosure. Due to the above inconclusive results, we will assume no directional relationship as illustrated below:

H1a: There is a relationship between being publicly listed on EGX and extent of the CSR disclosure and its sub-indices.

H1b: There is a relationship between being publicly listed on EGX and quality of the CSR disclosure. 


\subsection{Peers Effect}

Based on legitimacy and intuitional theories, companies in specific industries are highly exposed to the public scrutiny and hence subject to direct or indirect pressure to follow isomorphic disclosure pattern. Ortas et al. (2015) describe that normative isomorphism results from the professionalization of decision makers in organizations, which reflects their similar socialization. As a result, managers running companies in similar industries or operating similar functions are expected to act with similar cognitive mind-sets which in its turn shape their behavior and produce similar behavioral patterns to reach similar solutions (Ortas et al., 2015). Similarly, Branco and Rodrigues (2006) and Muttakin and Khan (2014) highlighted that companies in industries involved in environmental activities are more inclined to provide environmental information. Meanwhile, companies in industries that are highly exposed to the public (i.e banks) or to the environment are more likely to concentrate on community issues. It is also reported that social responsibility disclosure by financial companies in Malaysia are more dedicated to disclosing product or service disclosure than environmental and energy, human resources or community information (Abu Hamid, 2004). Therefore, it is expected to find typical patterns of CSR disclosures by banks providing similar services. Islamic banks in Bangladesh used to have higher CSR disclosure level compared with conventional banks for both annual report and website disclosures (Sobhani et al., 2012). Based on the above argument, it is proposed that bank's specialty which is defined, in this study, as the type of legal activities provided by the banks (commercial versus non-commercial) may affect the bank's CSR disclosure in terms of its quality and quantity aspects. Thus, we can hypothesize that:

H2a: There is a positive relationship between bank specialty and quantity of the CSR disclosure and its sub-indices.

$\mathrm{H} 2 \mathrm{~b}$ : There is a positive relationship between bank specialty and quality of the CSR disclosure.

\subsection{Clients Effect}

Fatma and Rahman (2016) highlight that customer awareness about the CSR activities has a significant impact on their purchase intention. Khemir and Baccouche (2010) have also argued that large firms are exposed to greater pressure for social responsibility disclosure than smaller ones. Likewise, Darus et al. (2014) have announced that customers are powerful stakeholders in financial institutions and hence may have an influence on the CSR reporting especially when the ownership is concentrated. Rudyanto and Siregar (2018) found that consumers have a high pressure on the quality of sustainability report. Hu and Scholtens (2014) have also studied 402 banks in the 44 developing countries including Egypt. The researchers investigated, for the first time, the impact of country freedom on the extent of CSR disclosure. The researchers argue that country citizens' voice allows for stakeholder and social pressure to materialize and for the interaction between banks and its society to occur (Hu \& Scholtens, 2014). Few studies have examined the clients' effect and referred to it as a bank exposure. Hence, it is hypothesized that:

H3a: There is a positive relationship between bank exposure and the extent of CSR disclosure and its sub-indices.

H3b: There is a positive relationship between bank exposures and quality of the CSR disclosure.

\subsection{External Auditor Effect}

The influence of auditors on the corporate voluntary disclosure is proved by previous research. For instance, Chen et al. (2016) remarked that audit fees are positively associated with the issuance of standalone CSR report. This influence has been getting increased in the recent years in parallel with the increase of voluntary provision which lack credibility and reliability. (Chen et al., 2016) argue that there the current CSR reporting lacks credibility because firms can voluntarily disclose environmental and social information in a strategic fashion. This is due to the fact that CSR reporting is so far not subject to generally accepted rules or mandatory review. For instance, (Jain et al., 2015) examined four Asia-Pacific countries and confirmed that there is no legislative requirement for CSR reporting. Yet, the CSR disclosure has been guided by the international standards which causes many discrepancies in terms of the name of the assurance statements, objectives, scope, use of assurance guidelines and even the created formats and followed approaches. Accordingly, assuring CSR disclosure has become costly and less commonly adopted in many countries (Charles et al., 2014). It is argued some companies may take the CSR seriously, by providing standalone report or assuring services, to carry out duties of accountability towards their stakeholders. Others could symbolically carry out their CSR activities just to present that they are genuinely committed to CSR (Michelon et al. 2015). Bello and Meka (2014) announce that despite the issuance of Sustainability Assurance Standard AA1000AS, which requires professional accountants to review the full range of organization's performance based on the principles of materiality, completeness and responsiveness, no agreed internal auditing standards for CSR and reporting of socio/environmental areas as adopted by banks in developed countries. Nevertheless, many researchers reported positive and significant impact of the auditor firm type and the extent of CSR. Therefore, we can 
hypothesize that:

H4a: There is a positive relationship between auditors' type and CSR total disclosure level and its sub-components.

H4b: There is a positive relationship between auditors' type and quality of the CSR disclosure.

\subsection{Governance Effect}

Corporate governance has a predominant impact on the extent and quality of the corporate disclosure in general and on the CSR disclosure, in particular. This has encouraged increasing number of researchers to study the relations between governance mechanisms and the corporate social and environmental disclosures such as (Khan et al., 2013, Giannarakis, 2014; Jizi et al., 2014; Gunawan, 2015; Habbash, 2016; and Rudyanto \& Siregar, 2018). For example, Chan et al. (2014) have studied the impact of corporate governance quality on the CSR and other seven types of CSR disclosures. A positive significant relationship was reported between the quality of corporate governance and four types of CSR disclosures namely; environment, energy, human resources, and products (Chan et al., 2014). Rudyanto and Siregar (2018) examined the effect of stakeholder pressure and corporate governance on the quality of sustainability report and found that board of commissioner effectiveness positively affects the quality of sustainability report. Sharif and Rashid (2014) have also scrutinized the CSR reporting activities by 22 commercial banks operating in Pakistan. The results reveal that Pakistani banks are largely dominated by independent directors and that the CSR disclosure is positively and significantly correlated with this measure. In this study, the governance impact is measured by focusing solely on two groups of stakeholders; independent directors and Audit committee (Fuente et al., 2017) announce that the role of the board of directors becomes more essential to enhance corporate transparency especially in the institutional environments that lack effective corporate control mechanisms (Fuente et al., 2017). Audit committee is also plays a fundamental role since it helps review the controls in place and the overall financial reporting process. As a result, its existence is essential to assure high quality financial reporting (Said et al, 2009). Previous research proved that existence of an audit committee is significantly and positively related to the extent of voluntary disclosure including CSR (Said et al., 2009; Babío Arcay \& Muiño Vázquez, 2005).

H5a: There is a significant positive relationship between independent directors and quantity of the CSR disclosure and its sub-indices.

H5b: There is a significant positive relationship between independent directors and quality of the CSR disclosure.

H6a: There is a significant positive relationship between audit committee size and quantity of the CSR disclosure and its sub-indices.

H6b: There is a significant positive relationship between audit committee size and quality of the CSR disclosure.

\subsection{Shareholders Effect}

As explained earlier, shareholders will be considered as internal stakeholders who possess a close relationship and direct interest in the bank profitability and sustainability. Hence, we will have categorized them into two main groups as shown below.

\subsubsection{Government Ownership}

CSR reporting is mostly voluntarily, however some countries have embarked to set regulations to make it compulsory as financial disclosure. In China, the government is keen to promote CSR in its own market-place. Consequently, Chinese entities now face greater pressure to engage in CSR activities to enhance their legitimacy (McGuinness et al. 2017). In Italy, the CSR disclosure is guided by the 'Social Statement' issued in 2003 and which is promoted by the Italian Government. This statement is a document that maps stakeholder-based CSR performance indicators, through which enterprises' methods of social, environmental and economic performance evaluation can be voluntarily supported and enhanced (Metaxas \& Tsavdaridou 2010). This argument is also supported by (Yeh et al., 2011). This line of argument is extended by Andrikopoulos et al., (2014) who stated that the impact of CSR practices in financial institutions goes beyond "national" stock markets, regional regulatory settings and religious background; it is of international character, to the extent that sustainable development is an international cause. According to the above argument, we will investigate the impact of government on the CSR disclosure not as a legislator but as a shareholder so can hypothesize that:

H7a: There is negative relationship between government ownership and quantity of the CSR disclosure and its sub-indices.

H7b: There is negative relationship between government ownership and quality of the CSR disclosure. 


\subsubsection{Foreign Ownership}

Foreign shareholders, particularly the institutional ones, can exert a great influence on companies including banks to undertake the CSR activities and/or to disclose adequate information to the public. For instance, Boubkri et al. (2016) find that cross-listing has a positive effect on the CSR disclosure in countries with weaker institutions, lower country-level sustainability, and higher liability of foreignness, and for those operating in industries with high litigation risk. In Croatia, the CSR disclosure level for foreign banks operating in Croatia surpasses the disclosure by the domestic banks (Hernaus \& Stojanovic, 2015). Another study in Korea, reveals that foreign block shareholders may act as effective external monitors as they have a negative moderate effect on the control-ownership effect on the CSR disclosure (Sul et al., 2014). Likewise, in Bangladesh, Habib-Uz Zaman (2010) has found significant impact of foreign nationality of the board members of the private commercial banks on the level of CSR disclosure. On the contrary, Merve (2016) has studied the CSR disclosure by Turkish banks and found no significant difference between foreign and domestic banks concerning their online disclosure of CSR. Similar results attained in Tunis (Raida et al., 2017). Accordingly, we can hypothesize a non-directional relationship between foreign ownership and the CSR disclosure.

H8a: There is a relationship between foreign ownership and quantity of the CSR disclosure and its sub-indices.

H8b: There is a relationship between foreign ownership and quality of the CSR disclosure.

\section{Data Collection and Methodology}

\subsection{The Investigated Population}

In this study, the researchers have studied the CSR disclosure for 38 banks constituting the entire population of banks registered by the Central Bank during the year 2014-2015. The content analysis as a research instrument used here because it is the most often used in the previous studies dealing with CSRD (Khan, 2010; Lipunga, 2013; Al Janadiet al., 2013; Driss \& Jarboui, 2014; Rudyanto \& Siregar, 2018...). It depends on GRI (2006), GRI (2008) supplementary reporting guidelines for the financial services sector, AA1000, UN Global Compact, Egyptian corporate governance code. The CSR indices (Appendix 2 and 3) have been previously developed by Arafa and ElHawary (2017) is used in this study to examine the effect of stakeholders on the CSR quality and quantity level. As banks employ various communication methods with their stakeholders, the CSR contents has been captured from several sources namely; annual reports, sustainability reports (available only for 13 banks) and banks' websites. In addition, the independent and control variables are downloaded from two main databases; Bank Scope and Thomson Reuters. These databases are the most updated and reliable sources used by academics and professionals.

The table below illustrates the characteristics of the examined banks. Only 16 of the total banks (42\%) were listed on the EGX and more than half of the banks 26 (68\%) possess 60 branches or more. However, the number of national banks $12(30 \%)$ is smaller than the foreign banks. Interestingly, 16 (42\%) banks are owned by government (Egyptian and Non-Egyptian) and the remaining banks are owned by other institutional shareholders. In terms of bank specialty, the majority 29 banks (76\%) considered as commercial. Meanwhile, the remaining 9 banks include one investment bank and other 5 specialized banks such as Bank Misr Iran for development, Housing and Development Bank, Export Development Bank and Principal Bank for Development in addition to Agricultural Credit of Egypt. Moreover, there are only 3 banks which are classified as Islamic banks; Abu Dhabi Islamic Bank, Al Baraka Bank of Egypt S.A.E. and the most popular one Faisal Islamic Bank of Egypt. 
Table 1. The population of studied banks

\begin{tabular}{llll}
\hline Bank Attributes & & $\mathbf{N}$ & $\mathbf{\%}$ \\
\hline \multirow{2}{*}{ Listing on EGX } & Non-listed & 22 & $57.9 \%$ \\
\cline { 2 - 4 } & Listed & 16 & $42.1 \%$ \\
\hline \multirow{2}{*}{ Number of Branches } & $>$ than 60 & 12 & $31.6 \%$ \\
\cline { 2 - 4 } & < than 60 & 26 & $68.4 \%$ \\
\hline Country of the headquarter & Non-Egyptian & 26 & $68.4 \%$ \\
\cline { 2 - 4 } & Egyptian & 12 & $31.6 \%$ \\
\hline Ownership type & Non-Governmental & 22 & $57.9 \%$ \\
\cline { 2 - 4 } & Governmental & 16 & $42.1 \%$ \\
\hline Bank Speciality & Non-commercial & 9 & $24 \%$ \\
\cline { 2 - 4 } & Commercial & 29 & $76 \%$ \\
\hline Total population $(\mathrm{N})$ & & $\mathbf{3 8}$ & $\mathbf{1 0 0 \%}$ \\
\hline
\end{tabular}

\subsection{Independent Variables}

The independent variables represent eight groups of stakeholders with a specific influence on the CSR disclosure. The measures and codes of these variable appear on Appendix 1. The first variable is being listed on the EGX (X1) may stimulate banks to disclose specific items to the public in a professional and/or highly organized manner. The listing status will be measured by dichotomous variables $(0,1)$ as shown in the Appendix 1 . All listed banks on the EGX will be assigned " 1 ", or " 0 " if otherwise.

The second independent variable reflects the effect of the peers which operate in the same industry or providing similar services and denoted by bank specialty (X2). According to legitimacy theory, companies follow the same disclosure pattern as their peers to maintain their legitimacy. It is argued that CSR disclosure and be institutionalized via professionalization at a global (De Villiers \& Alexander, 2014) or at industrial level (Kansal et al., 2014; Muttakin \& Khan, 2014). Hence, commercial banks are expected to provide analogous disclosure that differ from those provided by non-commercials. To measure this effect, bank specialty will be categorized into commercial and non-commercial. This variable will be assigned dichotomous values of $(1,0)$, whereby commercial banks will be assigned " 1 " and " 0 " if otherwise. It is argued that the more visible the bank, the higher the CSR disclosure will be (Andrikopoulos et al., 2014). Therefore, the third independent variable captures the effect of bank exposure (X3) on the CSR disclosure. This variable will be measured in two different ways; by the absolute number of branches possessed by the bank and by assigning dichotomous values of ( 1 and 0$)$. The bank with large exposure (i.e. possessing 60 or more branches) will be assigned " 1 " and " 0 " if otherwise.

The external auditors represent the forth independent variable (X4) who monitor banks' management and entitled to govern their opportunistic behavior. As a result, they may contribute a lot to the improvement of CSR disclosure. The impact of the external audit firm will be measured by assigning "1" to Big 4 audit firms and "0" if otherwise.The impact of internal governance mechanisms is examined by considering two types of stakeholders; the independent directors and audit committee. Presence of independent directors on the board represents the fifth independent variable (X5) which is expected to raise the management awareness and commitment towards the social activities. Following the pertinent research, it will be measured as a percentage of the directors' number to the total of board members. Audit committee is another means of internal governance who plays a profound role in raising the transparency of firm disclosure (financial and non-financial). The audit committee represents the sixth independent variable (X6) which is measured by absolute number of members in the committee.

The remaining independent variables represent a unique type of stakeholders who are the shareholders. They may have values, manners or beliefs related to social and environmental issues which may have an influence on their investment decisions. The two groups of shareholders that will be examined are the foreign shareholders (X7) and the governmental shareholders (X8). These variables are measured as a percentage of shares owned. Table (2) exhibits the descriptive statistics of the above variables. The control variables represent some financial characteristics of the banks and has also appeared at the bottom of table 2. The dichotomous independent variables have been presented in table 1 . 
Table 2. Descriptive statistics of the continuous independent and control variables

\begin{tabular}{lrrrrrr}
\hline Variables. & Mean & Median & SD & Skewness & Min & Max \\
\hline PINDDIER & 0.2273 & 0.1429 & 0.2609 & 1.1241 & 0.0000 & 0.8750 \\
\hline AUDITCOMM & 3.4474 & 3.0000 & 0.7240 & 1.7716 & 3.0000 & 6.0000 \\
\hline GOVESHARRATIO & 0.2444 & 0.0000 & 0.3718 & 1.1576 & 0.0000 & 1.0000 \\
\hline FOREINOWNERSHIP & 0.5464 & 0.5980 & 0.4205 & -0.2320 & 0.0000 & 1.0000 \\
\hline ROAE & 0.0450 & 0.1743 & 0.6969 & -5.9044 & -4.0811 & 0.3813 \\
\hline TOTALASSETS & 12221645.72 & 3700034.00 & 22178362.063 & 3.220 & 309583 & 110704915 \\
\hline TIERONELEVERAGE & 0.2409 & 0.0785 & 0.66173 & 4.552 & 0.01 & 3.65 \\
\hline
\end{tabular}

4.3 The Dependent Variables: CSR Qualitative and Quantitative Indices

The researchers have developed two main indices; CSR quantitative indices and CSR qualitative indices. The first index aggregates the scores of other sub-indices representing different CSR information which are employee, environment, community, product and customer in addition to Islamic related activities. The latter index is included as many Arabic banks used to disclose some data related their Islamic banking services.

The content analysis method has been employed to collect the data of the dependent variables as followed by prior studies (Raida et al., 2017, Alotaibi \& Hussainey, 2016a). This index consists of some disclosure categories, as employees, environmental issues, products and services, community involvement, customers, and other disclosure items which are consistent and compatible with the culture and the economic environment under examination, and justified by the fact that these information categories are the most used in previous studies dealing with the CSRD (Abdul Hamid, 2004; Douglas et al., 2004; Akano et al., 2013; and Lipunga, 2013). Pursuing this approach entails assigning " 1 " if the disclosure item exists in the bank annual report, or on the website or in the sustainability report and " 0 " if missing. Also, if the disclosure item is not related to the bank's activities, it is identified as Not Applicable (NA). To assure reliability while conducting the content analysis one researcher has been devoted for the coding process and another researcher reviewed the data collected by the first one. If discrepancies or missing data are found, the two researchers set together to reanalyze the content and resolve any evident inconsistencies.

The CSRQDI and CSRQLDI are developed by computing the ratio of awarded scores for specific criterion to the total number of items applicable to the bank. This method has been widely followed by many researchers such Haniffa and Cooke (2005). The following equation is used to calculate the CSR disclosure score.

$$
\text { CSRQUALINDEX }=\sum_{n j}^{n j} X_{i j}
$$

Where: CSRQUALINDEX = Corporate social responsibility quantitative index.

$\mathrm{nj}=$ number of items expected for $\mathrm{jth}$ firm. The value of $\mathrm{n}$ counts on the number of disclosure item constituting an index.

$\mathrm{Xij}=1$, if ith items are disclosed for bankj, otherwise 0 . Hence, the expected value of $\mathrm{Xij}$ is $0 \leq \mathrm{CSRQDIj} \leq 1$.

The CSRQUALINDEX is categorical value where four ranks have been assigned to each criterion. Each rank represents a grading level of quality whereby 1 represents the lowest quality level and 4 the highest quality level (as shown in appendix 2).

\subsection{Regression Models}

An ordinary least square multiple regression is applied to test the hypotheses proposed by this research. The regression models representing the CSR quantity and quality indices and the CSR sub-indices are defined below:

CSRQUANINDEX $=\alpha+\beta_{1}$ LIST_STATUS $+\beta_{2}$ B_SPECIALTY $+\beta_{3}$ B_BRANCH $+\beta_{4}$ AUDIT_TYPE $+\beta_{5}$ PINDDIER $+\beta_{6}$ AUDITCOM_SIZE $+\beta_{7}$ GOVE_RATIO $+\beta_{8}$ FOREIN_RATIO $+\beta_{9}$ T_ASSETS $+\beta_{10}$ $\mathrm{ROAE}+\beta_{11}$ LEVERAGE $+\varepsilon$

CSRQUALINDEX $=\alpha+\beta_{1}$ LIST_STATUS $+\beta_{2}$ B_SPECIALTY $+\beta_{3}$ B_BRANCH $+\beta_{4}$ AUDIT_TYPE $+\beta_{5}$ PINDDIER $+\beta_{6}$ AUDITCOM_SIZE $+\beta_{7}$ GOVE_RATIO $+\beta_{8}$ FOREIN_RATIO $+\beta_{9} \bar{T} \_$ASSETS + $\beta_{10}$ ROAE $+\beta_{11}$ LEVERAGE $+\varepsilon$ 


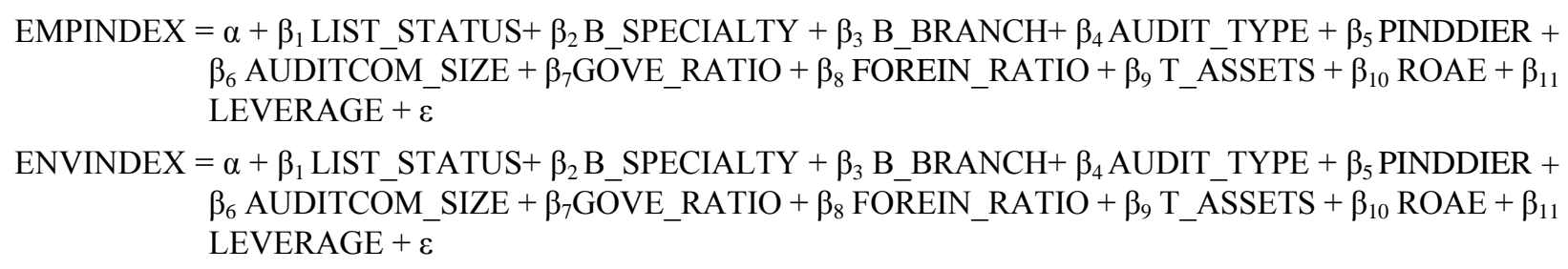

4.4.1 Dependent Variables:

CSRQDI = Corporate social responsibility quantity disclosure index, measured by score/index.

CSRQLDI $=$ Corporate social responsibility quality disclosure index, measured by weighted ranks.

EMPINDEX $=$ Employee/human resource disclosure index, measured by score/index

ENVINDEX $=$ Environment disclosure index, measured by score/index

COMMINDEX $=$ Community disclosure index, measured by score/index .

4.4.2 Independent Variables:

LIST-STATUS $=$ being listed on EGX

B-BRANCHES $=$ bank exposure.

FOREIN- RTIO $=$ Foreign ownership

GOV-RATIO = Government ownership (either Egyptian or non-Egyptian).

AUDT-TYPE = Auditor Type

PINDDIER $=$ Percentage of independent directors relative to the board size.

AUDITCOMM $=$ Size of audit committee.

\subsubsection{Control Variables}

T-ASSETS $=$ represents the bank size and measured by the natural logarithm of total assets;

LEVERAGE = represents the bank's capital adequacy. The ratio is measured by tier on capital to average total risky assets and is used as a proxy of the leverage ratio.

$\mathrm{ROAE}=$ Return on capital employed used as a proxy of profitability.

$\varepsilon=$ residual factor.

\section{Empirical Results}

\subsection{The Univariate Analysis}

Table 3 demonstrates the association between CSR index and its sub-indices and the explanatory variables using Spearman's Rho correlation coefficients. It can be realized that the dependent variables are highly correlated with each other, except for Islamic related activities index as it is not normally part of the CSR disclosure. It is also evident that (LIST-STATUS) is positive, but not significantly associated with all CSR indices. However, (B-SPECIALITY) is positively and significantly associated with three indices; (CSRQUA), (ENVIRO) and (CUSTINDEX).

Bank exposure measured by the number of owned branches (B_BARNCHES) is negatively but insignificantly associated with all CSR indices except for the (ISLAMICINDEX). It is significant only with the (COMMINDEX). Unlike the bank exposure, (AUDIT_TYPE) is positively but not significantly associated with all CSR indices except 
for (ISLAMICINDEX). However, it is only significant with (ENVINDEX) and (CUSTINDEX). The governance indicators show consistent results. For instance, the (PINDDIR) is positively associated with all the CSR indices, but significant only with (ENVINDEX) and (CUSTINDEX). The (AUDITCOM_SIZE) is positively and significantly associated with previous indices as well as (CSRQUANINDEX) and (CSRQUALINDX). Regarding the ownership type, the (GOVE_RATIO) is insignificant with all CSR indices meanwhile foreign ownership is positive and significant with the (ENVIDEX) only.

Finally, the bank size proxied by (T_ASSETS) shows significant positive association with all CSR indices. However, leverage ratio proxied by the tier one leverage is negatively significant with CSRQUALINDEX and COMMINDEX and insignificant with the remaining indices. As the univariate analysis fails to capture the significance of the dependent variables, the subsequent multivariate analysis will be conducted to re-examine the robustness of previously defined associations and to determine the predictive power of the underlaying explanatory variables.

Table 3. Spearman's rho correlation matrix

\begin{tabular}{|c|c|c|c|c|c|c|c|c|c|c|c|c|c|c|c|c|c|c|}
\hline & $\begin{array}{l}\text { CSRQUA } \\
\text { NINDEX }\end{array}$ & $\begin{array}{l}\text { CSRQU } \\
\text { AL INDX }\end{array}$ & $\begin{array}{l}\text { EMP } \\
\text { INDEX }\end{array}$ & $\begin{array}{l}\text { ENV } \\
\text { IDEX }\end{array}$ & $\begin{array}{l}\text { СОМм } \\
\text { INDEX }\end{array}$ & $\begin{array}{l}\text { CUST } \\
\text { INDEX }\end{array}$ & $\begin{array}{l}\text { ISLAMIC } \\
\text { INDEX }\end{array}$ & $\mathbf{x} 1$ & $\mathrm{x} 2$ & $\mathrm{x} 3$ & $\mathrm{x} 4$ & $\mathrm{X} 5$ & $\mathrm{X} 6$ & $\mathrm{x} 7$ & $\mathrm{x} 8$ & x9 & $\mathrm{x} 10$ & $\mathrm{x} 11$ \\
\hline CSRQUANINDEX & 1.000 & & & & & & & & & & & & & & & & & \\
\hline CSRQUALINDX & $.863^{\prime \prime}$ & 1.000 & & & & & & & & & & & & & & & & \\
\hline EMPINDEX & $.815^{*}$ & $.775^{\circ}$ & 1.000 & & & & & & & & & & & & & & & \\
\hline ENVIDEX & $.860^{\circ}$ & $.768^{\circ}$ & $.736^{\prime \prime}$ & 1.000 & & & & & & & & & & & & & & \\
\hline COMMINDEX & $.822 *$ & $.769^{\circ}$ & $.602^{*}$ & $.681^{\circ}$ & 1.000 & & & & & & & & & & & & & \\
\hline CUSTINDEX & $.571^{\prime \prime}$ & $.640^{\circ}$ & $.339^{\circ}$ & $.572^{\circ}$ & $.486^{*}$ & 1.000 & & & & & & & & & & & & \\
\hline ISLAMICINDEX & .120 & -.123 & -.014 & .085 & -.264 &. .149 & 1.000 & & & & & & & & & & & \\
\hline LIST_STATUS & .183 & .083 & .244 & .033 & .027 & .103 & .231 & 1.000 & & & & & & & & & & \\
\hline B_SPECIALITY & .311 & $.334^{\circ}$ & .271 & $.551^{\circ}$ & .279 & $.331^{\circ}$ & -.218 & .026 & 1.000 & & & & & & & & & \\
\hline B_BRANCH & -.127 & -106 & .075 & -.035 & -.333 &. .194 & .107 & .006 & .021 & 1.000 & & & & & & & & \\
\hline AUDIT_TYPE & .204 & .133 & .200 & $.322^{\circ}$ & .163 & $.355^{\circ}$ & -.151 &.,- 161 & .190 & .066 & 1.000 & & & & & & & \\
\hline PINDDIR & .228 & .166 & .257 & $.328^{\circ}$ & .214 & $.449^{* \prime}$ & .066 & .157 & $.34^{\circ}$ & .087 & $.348^{\circ}$ & 1.000 & & & & & & \\
\hline AUDITCOM_SIZE & $.390^{\circ}$ & $.322^{\circ}$ & .286 & $.339^{\circ}$ & .311 & $.420^{\prime \prime}$ & .042 & -.061 & .277 & -.059 & .082 & $.512^{\prime \prime}$ & 1.000 & & & & & \\
\hline GOVE_RATIO & -108 & .063 & -.266 & .014 & -179 & .072 & .092 & $-.323^{\circ}$ & .055 & .063 & -.187 & -.200 & -.019 & 1.000 & & & & \\
\hline FOREIN_RTIO & .260 & .128 & .215 & $.462^{*}$ & .250 & .275 &. .180 & -.042 & $.421^{\prime \prime}$ & 0.000 & $.496^{*}$ & $.499^{*}$ & $.363^{\circ}$ & .230 & 1.000 & & & \\
\hline ROAE & .092 & .093 & .174 & .070 & .182 & .091 &. .165 & .306 & -.008 & $-.511^{*}$ & .011 & -.024 & .056 & -.151 & .168 & 1.000 & & \\
\hline T_ASSETS & $.472^{* \prime}$ & $.430^{\circ}$ & $.405^{\circ}$ & $.422^{\circ}$ & $.381^{\circ}$ & .185 & .193 & .133 & $.334^{\circ}$ & $.461 "$ & -.052 & .042 & .073 & .070 & .020 & $.373^{\circ}$ & 1.000 & \\
\hline LEVERAGE & $.377^{\circ}$ & -.298 & -093 &. .189 & $-.423^{* \prime}$ & -.048 & -.248 & -.024 & .003 & $.346^{\circ}$ & .108 & .164 & .051 & .273 & -.005 & -.174 & $.508^{* \prime}$ & 1.000 \\
\hline
\end{tabular}

\subsection{The Multivariate Results}

Table 4 below is divided into panel A and Panel B. Each panel shows the regression models for the CSR main and sub-indices. The components of these panels are slightly different from each other as Panel A includes FOREIN-RTIO, while panel B does not. Likewise, Panel B includes two explanatory variables which are not included in panel A; ROAE and PINDDIR. Separating these explanatory variables is necessary to avoid the occurrence of multicollinearity. The generated OLS regression results provide relatively low level of adjusted $\mathrm{R}^{2}$ for the seven indices. This suggests that there are more pertinent variables explaining the changes in the underlying independent variables not included in our predicting models. 
Table 4. Regression matrix for the CSR main indices and sub-indices

\begin{tabular}{|c|c|c|c|c|c|c|c|}
\hline Panel A & CSRQUAN & CSRQUAL & EMP & ENV & COMM & CUST & ISLAMIC \\
\hline & INDEX & INDEX & INDEX & INDEX & INDEX & INDEX & INDEX \\
\hline Constant & -28.171 & -10.523 & -51.981 & -33.483 & 4.234 & 22.408 & -10.056 \\
\hline sig & 0.286 & 0.721 & 0.067 & 0.186 & 0.865 & 0.393 & 0.686 \\
\hline AUDIT_TYPE & $7.681 *$ & 4.649 & 4.723 & 5.142 & 2.147 & $10.135^{* *}$ & 4.210 \\
\hline sig & 0.093 & 0.358 & 0.316 & 0.232 & 0.636 & 0.030 & 0.324 \\
\hline AUDITCOM_SIZE & $0.473 * *$ & $0.389 *$ & 0.327 & 0.219 & $0.347 *$ & $0.433 * *$ & 0.145 \\
\hline sig & 0.017 & 0.074 & 0.105 & 0.226 & 0.071 & 0.027 & 0.418 \\
\hline B_SPECIALITY & 3.714 & 5.798 & 3.486 & $7.616^{*}$ & 0.420 & 4.601 & -3.962 \\
\hline sig & 0.432 & 0.279 & 0.481 & 0.098 & 0.931 & 0.331 & 0.379 \\
\hline B_BRANCH & 1.622 & -0.676 & 5.357 & 2.950 & $6.217 * *$ & -5.157 & 5.743 \\
\hline Sig & 0.729 & 0.898 & 0.281 & 0.510 & 0.033 & 0.275 & 0.204 \\
\hline LIST_STATUS & $6.533^{*}$ & 1.609 & 2.362 & 2.723 & 3.857 & $6.937 *$ & $8.441 * *$ \\
\hline sig & 0.092 & 0.705 & 0.551 & 0.451 & 0.349 & 0.074 & 0.025 \\
\hline GOVE_RATIO & 0.133 & -0.037 & -0.301 & 0.129 & -.368 & 0.308 & $0.405^{*}$ \\
\hline sig & 0.538 & 0.877 & 0.189 & 0.529 & 0.135 & 0.158 & 0.056 \\
\hline FOREIN_RTIO & -0.028 & -0.211 & -0.118 & 0.184 & 0.062 & -0.075 & -0.027 \\
\hline sig & 0.886 & 0.348 & 0.571 & 0.334 & 0.753 & 0.703 & 0.886 \\
\hline LEVERAGE & $-0.341 *$ & -0.270 & 0.108 & -0.166 & -0.252 & -0.202 & -0.265 \\
\hline sig & 0.079 & 0.212 & 0.587 & 0.359 & 0.212 & 0.289 & 0.148 \\
\hline ROAE & -0.066 & -0.059 & 0.127 & -0.006 & -0.256 & -0.097 & -0.132 \\
\hline Sig & 0.732 & 0.787 & 0.533 & 0.974 & 0.220 & 0.617 & 0.473 \\
\hline T_ASSETS & 2.075 & 1.685 & $3.762 * *$ & 2.169 & 0.014 & -1.304 & 1.220 \\
\hline Sig & 0.200 & 0.352 & 0.032 & 0.161 & 0.993 & 0.415 & 0.423 \\
\hline \multicolumn{8}{|l|}{ Model summary } \\
\hline$R$-square & 0.510 & 0.349 & 0.399 & 0.489 & 0.508 & 0.410 & 0.348 \\
\hline Adjusted $R^{2}$ & 0.315 & 0.088 & 0.158 & 0.284 & 0.303 & 0.174 & 0.087 \\
\hline$F$-statistics & $2.607 *$ & 1.337 & 1.659 & $2.388^{*}$ & $2.476^{*}$ & 1.736 & 1.334 \\
\hline Sample size & 36 & 36 & 36 & 36 & 36 & 36 & 36 \\
\hline
\end{tabular}

Note: *,**, and $* * *$ represent significance levels at $10 \%, 5 \%$, and $1 \%$ respectively. 


\begin{tabular}{|c|c|c|c|c|c|c|c|}
\hline Panel B & $\begin{array}{c}\text { CSRQUAN } \\
\text { INDEX }\end{array}$ & $\begin{array}{l}\text { CSRQUAL } \\
\text { IDEX }\end{array}$ & $\begin{array}{c}\text { EMP } \\
\text { INDEX }\end{array}$ & $\begin{array}{c}\text { ENV } \\
\text { INDEX }\end{array}$ & $\begin{array}{l}\text { COMM } \\
\text { INDEX }\end{array}$ & $\begin{array}{c}\text { CUST } \\
\text { INDEX }\end{array}$ & $\begin{array}{l}\text { ISLAMIC } \\
\text { INDEX }\end{array}$ \\
\hline Constant & 6.471 & 7.953 & 7.204 & 2.289 & $14.627 *$ & -2.471 & $21.358 * * *$ \\
\hline sig & .381 & 0.346 & 0.388 & 0.749 & 0.076 & 0.730 & 0.006 \\
\hline AUDIT_TYPE & 7.758* & 5.102 & 5.188 & $6.757 *$ & 3.005 & 7.749* & 2.484 \\
\hline sig & 0.059 & 0.266 & 0.253 & 0.090 & 0.49 & 0.054 & 0.531 \\
\hline AUDITCOMSIZE & $.507 * *$ & $0.405^{*}$ & 0.325 & 0.235 & 0.277 & 0.318 & 0.127 \\
\hline $\operatorname{sig}$ & 0.017 & 0.088 & 0.163 & 0.240 & 0.217 & 0.116 & 0.531 \\
\hline B_SPECIALTY & 4.876 & 7.284 & 6.325 & $10.423 * *$ & 3.858 & 1.732 & -4.854 \\
\hline $\operatorname{sig}$ & 0.235 & 0.123 & 0.174 & 0.013 & 0.386 & .662 & 0.235 \\
\hline LIST_STATUS & $7.464 * *$ & 3.819 & 4.771 & 3.054 & 0.575 & 5.410 & $8.293 * *$ \\
\hline sig & .050 & 0.366 & 0.256 & 0.397 & 0.886 & 0.139 & 0.030 \\
\hline GOVE_RATIO & 0.182 & 0.113 & -0.160 & 0.166 & -0.008 & $0.342 *$ & $0.340^{*}$ \\
\hline sig & 0.337 & 0.599 & 0.452 & 0.370 & 0.970 & 0.070 & 0.077 \\
\hline PINDDIR & -.110 & -0.140 & -0.108 & 0.041 & 0.079 & 0.222 & -0.038 \\
\hline sig & 0.595 & 0.555 & 0.646 & 0.840 & 0.727 & 0.278 & 0.854 \\
\hline ROAE & -.099 & -0.032 & 0.047 & -0.008 & 0.86 & 0.013 & $-.294 *$ \\
\hline sig & 0.509 & 0.852 & 0.781 & 0.954 & 0.601 & 0.929 & $\mathbf{0 . 0 5 7}$ \\
\hline LEVERAGE & $-.456 * * *$ & $-0.323 *$ & -0.032 & $-0.269 *$ & $-0.499 * *$ & -.219 & $-.327 * *$ \\
\hline sig & 0.006 & 0.073 & 0.853 & 0.081 & 0.011 & 0.151 & 0.039 \\
\hline \multicolumn{8}{|l|}{ Model summary } \\
\hline$R$-square & 0.474 & 0.281 & 0.315 & 0.445 & 0.361 & 0.417 & 0.294 \\
\hline Adjusted $R^{2}$ & 0.324 & 0.076 & 0.120 & 0.287 & 0.179 & 0.251 & 0.092 \\
\hline$F$-statistics & $3.158 *$ & 1.370 & 1.612 & 2.812* & $1.979 *$ & $2.505 *$ & 1.455 \\
\hline Sample size & 36 & 36 & 36 & 36 & 36 & 36 & 36 \\
\hline
\end{tabular}

Note: The dependent variables: CSRQANINDEX = CSR total quality index; CSRQUALINDEX= CSR total quality index; EMPINDEX= Employees index; ENVINDEX= Environmental index; COMMINDEX =Community index; CUSTINDEX= Customer and product index; ISLAMICINDEX=Islamic activities index. The independent variables are: AUDIT_TYPE=Auditor type (dichotomous variable, $1=$ Big 4,0 =otherwise); AUDITCOMSIZE = number of the members on the audit committee); $\mathrm{B}_{-}$ SPECIALTY= Bank specialty (dichotomous variable, $1=$ commercial, $0=$ otherwise); LIST_STATUS = Being listed on EGX $($ lif listed on EGX, 0 if otherwise); GOVE_RATIO = percentage of shares owned by government; FOREIN_RTIO = percentage of the shares owned by Foreign and Arabic governments or corporates. PINDDIR= Percentage of independent directors to the total board size; ROAE = Return on average equity; LEVERAGE = Represents the capital adequacy ratio and measured by tier on capital to average total risky assets; T_ASSETS= Represents bank size and measured by the natural log of the total assets in Y2015. B_BRANCH= represents the bank exposure level and measured as a dichotomous variable (1if banks with high exposure which possess more than 60 branches in Egypt, 0 if otherwise)

Note: *,**, and *** represent significance levels at $10 \%, 5 \%$, and $1 \%$ respectively

H1: predicts the impact of being listed on the EGX on the CSR overall disclosure. It has been further divided into two sub-hypotheses; H1a: There is a relationship between being publicly listed on EGX and quantity of the CSR disclosure and its sub-indices and $\mathrm{H} 1 \mathrm{~b}$ : There is a relationship between being publicly listed on EGX and quality of the CSR disclosure. Table 8-panel (A) shows that LIST_STATUS has a significant positive relationship with the CSRQUANINDEX $(\beta=6.533)$ and CUSTINDEX $(\beta=6.533)$ at $p<0.10$ and ISLAMICINDEX $(\beta=8.441)$ at $p<$ 0.05. Similar results are shown on panel (B) for CSRQUAN and ISLAMICINDEX. This result implies that listed banks provide higher level of total CSR disclosure, Customer and Product as well as Islamic activities. This result is consistent with (Mohamed Chakib, 2017) who studied the CSR disclosure by 25 companies listed on Abu Dhabi Security Exchange. 
$\mathrm{H} 2$ : predicts the relationship between bank's specialty and the CSR quality and quantity aspects. It is divided into two sub-hypotheses; H2a: There is a positive relationship between bank specialty and quantity of the CSR disclosure and $\mathrm{H} 2 \mathrm{~b}$ : There is a positive relationship between bank specialty and quality of the CSR disclosure. The empirical results appeared on panel $\mathrm{A}$ and $\mathrm{B}$ of table 8 demonstrate significant relationship between this variable and (ENVINDEX) $(\beta=7.616)$ at $p<0.10$ and $(\beta=10.423)$ at $p<0.05$ respectively. This indicates that banks involved in commercial activities are more inclined to disclose more environmental information. The results are consistent with Khan et al., (2009) who conducted a research on Bangladesh commercial banks and found that these banks are more incliened to disclose information on topics related to responsibility towards public health, safety and facilities for the community rather than environmental issues.

H3: predicts the impact of bank exposure on the CSR quality and quantity aspects. Accordingly, H3a postulates that there is a positive relationship between bank exposure and quantity of the CSR disclosure and its sub-indices. However, $\mathrm{H} 3 \mathrm{~b}$ postulates that there is a positive relationship between bank exposure and quality of the CSR disclosure. The results revealed that there is no significant impact on the CSR quantity and quality indices except for COMMINDEX whereby banks with little exposure to public (i.e. possessing less than branches) have significant higher disclosure score than the banks with more exposure at $p<0.05$. Further analysis, combines the effect of bank specialty and bank exposure, has proved that commercial and non-commercial banks with little exposure have higher score of COMMINDEX (Mean= 0.79), (Mean= 0.72) than commercial banks with higher exposure (Mean=0.59). This finding partially implies that bank exposure has insignificant impact on the CSR quantity and quality aspects except for the community index. This result is inconsistent with (Branco \& Rodrigues, 2006) who concluded that banks with higher visibility to community used to disclose more environmental and community information which constitutes part of their legitimation strategies. In Egypt, banks with higher visibility used to disclose more community information compared to other CSR disclosures. Yet, the overall results are insignificant and this indicates that banks' clients are not involved in the banks CSR strategies. This is supported by Hu and Scholtens (2014) who stated that at the country level, financial development and freedom are favorable with regards to banks' CSR. Thus, we partially reject the H3 hypothesis.

$\mathrm{H} 4$ predicts the impact of auditor type on the CSR quantity and quality aspects whereby H4a states that there is a positive relationship between auditors' type and CSR total disclosure level and its sub-components and H4b states that there is a positive relationship between auditors' type and quality of the CSR disclosure. The univariate results shown in table 6 exhibit positive correlation with both of ENVINDEX and CUSTINDEX. This is consistent with the multivariate results appeared in the same table Whereby Panel A shows a significant positive relationship with the CSRQUANINDEX $(\beta=7.305)$ at $p<0.10$ and CUSTINDEX $(\beta=9.504)$ at $p<0$. 05. Likewise, panel B shows similar results in addition to significant relationship with the ENVINDEX $(\beta=6.757)$ at $p<0.10$. However, the results in both panel A and B do not show any relationship between auditor type and the CSRQUALINDEX. Hence, the H4a can partially be accepted meanwhile H4b is statistically rejected. Generally, H5 and H6 predict the impact of internal corporate governance on the CSR quantity and quality aspects. Thus, H5a predicts that there is a significant positive relationship between independent directors and the quantity of CSR disclosure. Meanwhile, H5b predict that there is a significant positive relationship between independent directors and quality of the CSR disclosure. The results show no significant relationship between the percentage of independent directors on board and the CSR main and sub-indices.

On the contrary, H6: predicts the impact of Audit committee on the CSR disclosure whereby H6a predicts that there is a significant positive relationship between audit committee size and the quantity of the CSR disclosure. H6b also predicts a significant positive relationship between audit committee size and quality of the CSR disclosure. The empirical results show that audit committee size is the most dominant predictor since the univariate as well as multivariate results in panel A show significant positive relationships with the CSR quantity $(\beta=0.482)$ as well as customer and product index $(\beta=0.429)$ at $p<0.05$. Similar results are reported for CSR Quality index $(\beta=0.385)$, Employee index $(\beta=0.301)$ and community index $(\beta=0.332)$ at $p<0.10$. Therefore, H5 is rejected and H6 is partially accepted.

These results are consistent with the findings of Said et al., (2009) who realized positive but weak significant relationship between audit committee and the total CSR disclosure of $(\beta=0.15)$ at $p<0.10$. It is also consistent with Chan et al. (2014) who found positive and significant relationship between CSR disclosure and corporate governance quality (at $\mathrm{p}<0.10$ ) for 300 listed firms on Australian Stock Exchange. Their results were applied to four CSR disclosure indices out of seven which are environment, energy, human resources, and products. However, our results are inconsistent with Habbash (2016) who studied the CSR by listed firms in the Kingdom of Saudi Arabia and found significant impact of independent directors, but not for the audit committee. Also, Sharif and Rashid (2014) reported 
positive significant relationship for the percentage of independent directors, but not for the presence of foreign directors on the board. Our findings reveal that audit committee has the most powerful impact on the CSR disclosure compared to the independent directors.

$\mathrm{H} 7$ and $\mathrm{H} 8$ are developed to predict the impact of shareholders on the CSR quantity and quality aspects. H7a predicts a negative relationship between government ownership and the quantity of the main CSR disclosure and other sub-indices. Likewise, $\mathrm{H} 7 \mathrm{~b}$ predicts a negative relationship between government ownership and the quality of CSR disclosure. Meanwhile H8a predicts a positive relationship between foreign ownership and the quantity of CSR and its sub-indices. Also, H8b predicts positive relationship between foreign ownership and the quality of CSR. For the government ownership, the multivariate results in table 8 - panel A show positive and significant relationship with ISLAMICINDEX only $(\beta=0.405)$ at $\mathrm{p}<0.10$. Same result appeared on Panel B in addition to another index; CUSTINDEX $(\beta=0.342)$ at $p<0.10$. These results contradict with (Said et al. 2009) who reported positive relationship between government ownership and total CSR disclosure $(\beta=0.20)$ at $p<0.05$. Yet, it is consistent with Darus et al. (2014) who found out that government is not a powerful influence of CSR disclosure in Malaysian financial institutions. On Similar results reported for non-financial Malaysian institutions, (Abdifatah, 2013). However, our results contradict with Said et al., (2009) in respect of government ownership, but consistent with foreign ownership which was also insignificant. In respect of the CSR quality index, both types of ownership have insignificant relationship. Accordingly, $\mathrm{H} 7$ is partially accepted, meanwhile $\mathrm{H} 8$ is totally rejected for the foreign ownership.

In terms of the control variables, profitability measured by ROAE had a negative but insignificant relationship with most of CSR indices except for ISLAMICINDEX which is also negative but significant $(\beta=-0.294)$ at $p<0.10$ as shown in Panel B. This indicates that profitability is not a good predictor of CSR disclosure for the banks operating in Egypt. Same insignificant but positive relationships are observed for the bank size with all the CSR indices except for EMPINDEX which was significant $(\beta=0.342)$ at $\mathrm{p}<0.05$ as shown in Panel A. Nevertheless, the results observed for leverage ratio which measures the capital adequacy in banks were all negative and significant with CSRQUANTINDEX $(\beta=-0.456)$ at $(p<0.001)$, CSRQUANLINDEX $(\beta=-0.323)$ at $\mathrm{p}<0.10$, ENVINDEX $(\beta=$ $-0.269)$ at $p<0.10$, COMMINDEX $(\beta=-0.499)$ at $p<0.05$ and ISLAMIC INDEX $(\beta=-0.327)$ at $p<0.05$. These results were contradicting with Chan et al. (2014) study which spotted positive and significant relationship, but consistent with Andrikopoulos et al. (2014) who argue that firm is exposed to a higher leverage are more inclined to disclose financial information rather than non-financial information due to the limited resources.

\subsection{Further Analysis: Non-Paramatric Test}

As some of the explanatory variables are nominal in nature, the researchers carried out further non-parametric test namely Mann-Wittney U. This analysis helps find out how significant the CSR disclosure differ across the banks based on multiple criteria. Mann-Witney $\mathrm{U}$ shape test is a nonparametric test that is distinguished for not being affected by normality assumptions.

\subsubsection{The Impact of Listing Status}

Though the disclosure score of the listed banks surpasses the score of the non-listed banks as in table 5, Mann-Whitney U shape results provide no significant difference. This implies that EGX still need more efforts to enhance the CSR disclosure by the listed banks.

Table 5. Nonparametric statistics of listing status

\begin{tabular}{lrrrrrrr}
\hline CSR indices & $\begin{array}{r}\text { EMP } \\
\text { INDEX }\end{array}$ & $\begin{array}{r}\text { ENV } \\
\text { INDEX }\end{array}$ & $\begin{array}{r}\text { COMM } \\
\text { INDEX }\end{array}$ & $\begin{array}{r}\text { CUST } \\
\text { INDEX }\end{array}$ & $\begin{array}{r}\text { ISLAMICIN } \\
\text { DEX }\end{array}$ & $\begin{array}{r}\text { CSRQUAL } \\
\text { INDEX }\end{array}$ & $\begin{array}{r}\text { CSRQUAL } \\
\text { IDEX }\end{array}$ \\
\hline Mann-Whitney U & 127.5 & 169.5 & 170.5 & 156.0 & 133.5 & 138.5 & 159.0 \\
\hline Wilcoxon W & 380.5 & 422.5 & 423.5 & 409.0 & 386.5 & 391.5 & 412.0 \\
\hline Z & -1.5 & -0.2 & -0.2 & -0.6 & -1.4 & -1.1 & -0.5 \\
\hline Sig. (2-tailed) & 0.1 & 0.8 & 0.9 & 0.5 & 0.2 & 0.3 & 0.6 \\
\hline Non-listed & 17.3 & 19.2 & 19.3 & 18.6 & 17.6 & 17.8 & 18.7 \\
\hline Listed & 22.5 & 19.9 & 19.8 & 20.8 & 22.2 & 21.8 & 20.6 \\
\hline
\end{tabular}




\subsubsection{The Impact of Ownership Type}

Table 6 below shows that non-governmental banks are performing better than governmental banks according to their mean ranks. Yet, this is only significant for the environment index at $\mathrm{p}<0.05$. This observation indicates that generally there is no significant differences between both governmental and non-governmental in respect of all disclosure indices. Nevertheless, it can be realized that non-governmental banks paid more attention to environmental disclosure.

Table 6. Nonparametric statistics of government ownership

\begin{tabular}{lcccccccc}
\hline CSR indices & $\begin{array}{c}\text { EMP } \\
\text { INDEX }\end{array}$ & $\begin{array}{c}\text { ENV } \\
\text { INDEX }\end{array}$ & COMMINDEX & $\begin{array}{c}\text { CUST } \\
\text { INDEX }\end{array}$ & $\begin{array}{c}\text { ISLAMC } \\
\text { INDEX }\end{array}$ & $\begin{array}{c}\text { CSRQUN } \\
\text { INDEX }\end{array}$ & $\begin{array}{c}\text { CSRQUAL } \\
\text { INDEX }\end{array}$ \\
\hline Mann-Whitney U & 128.0 & 111.5 & 146.5 & 128.0 & 169.0 & 129.5 & 151.5 \\
\hline Wilcoxon W & 264.0 & 247.5 & 282.5 & 264.0 & 305.0 & 265.5 & 287.5 \\
\hline $\mathrm{Z}$ & -1.5 & -2.0 & -0.9 & -1.5 & -0.2 & -1.4 & -0.7 \\
\hline Sig. (2-tailed) & 0.1 & $\mathbf{0 . 0}$ & 0.4 & 0.1 & 0.8 & 0.2 & 0.5 \\
\hline $\begin{array}{l}\text { Non-Governmental Mean } \\
\text { rank }\end{array}$ & 21.7 & 22.4 & 20.8 & 21.7 & 19.8 & 21.6 & 20.6 \\
\hline Governmental -Mean rank & 16.5 & 15.5 & 17.7 & 16.5 & 19.1 & 16.6 & & 18.0
\end{tabular}

In respect of the CSR by foreign owned banks as shown in table 7 confirms with our prior expectations and elucidates that the disclosure level of CSR of foreign banks, in general, is higher than that of the Egyptian banks. The results are significant for EMINDEX, ENVINDEX, and CUSINDEX at $\mathrm{p}<0.05$. This implies that Egyptian banks still behind the foreign and Arabic banks in terms of their CSR disclosure.

Table 7. Nonparametric statistics of foreign ownership

\begin{tabular}{lccccccc}
\hline CSR indices & $\begin{array}{c}\text { EMP } \\
\text { INDEX }\end{array}$ & $\begin{array}{c}\text { ENV } \\
\text { INDEX }\end{array}$ & COMMINDEX & $\begin{array}{c}\text { CUST } \\
\text { INDEX }\end{array}$ & $\begin{array}{c}\text { ISLAMIC } \\
\text { INDEX }\end{array}$ & $\begin{array}{c}\text { CSRQUAN } \\
\text { INDEX }\end{array}$ & $\begin{array}{c}\text { CSRQUAL } \\
\text { INDEX }\end{array}$ \\
\hline Mann-Whitney U & 82.0 & 64.0 & 129.0 & 94.5 & 139.5 & 97.5 & 111.5 \\
\hline Wilcoxon W & 160.0 & 142.0 & 207.0 & 172.5 & 490.5 & 175.5 & 189.5 \\
\hline Z & -2.4 & -3.0 & -0.9 & -2.0 & -0.6 & -1.8 & -1.4 \\
\hline Sig. (2-tailed) & $\mathbf{0 . 0}$ & $\mathbf{0 . 0}$ & 0.4 & $\mathbf{0 . 0}$ & 0.6 & 0.1 & 0.2 \\
\hline Foreign banks & 22.35 & 23.04 & 20.54 & 21.87 & 18.87 & 21.75 & 21.21 \\
\hline Egyptian banks & 13.33 & 11.83 & 17.25 & 14.38 & 20.88 & 14.63 & 15.79
\end{tabular}

5.3.3 The Impact of Bank Specialty

According to table 8 , it can be realized that the mean ranks for commercial banks are generally higher than those of non-commercial banks except for Islamic Index. This result makes sense as Islamic banks are those are entitled and more devoted for this unique type of disclosure. It is also evident that the difference between them is significant in terms of the ENVINDEX, CUSTINDEX and CSRQUAINDEX.

Table 8. Nonparametric statistics of bank specialty

\begin{tabular}{lccccccc}
\hline CSR indices & $\begin{array}{c}\text { EMP } \\
\text { INDEX }\end{array}$ & $\begin{array}{c}\text { ENV } \\
\text { INDEX }\end{array}$ & $\begin{array}{c}\text { COMM } \\
\text { INDEX }\end{array}$ & $\begin{array}{c}\text { CUST } \\
\text { INDEX }\end{array}$ & $\begin{array}{c}\text { ISLAMC } \\
\text { INDEX }\end{array}$ & $\begin{array}{c}\text { CSRQUAN } \\
\text { INDEX }\end{array}$ & $\begin{array}{c}\text { CSRQUAL } \\
\text { INDEX }\end{array}$ \\
\hline Mann-Whitney U & 84.0 & 36.5 & 81.5 & 75.0 & 96.0 & 75.5 & 71.5 \\
\hline Wilcoxon W & 129.0 & 81.5 & 126.5 & 120.0 & 531.0 & 120.5 & 116.5 \\
\hline $\mathrm{Z}$ & -1.7 & -3.4 & -1.7 & -2.0 & -1.3 & -1.9 & -2.0 \\
\hline Sig. (2-tailed) & 0.1 & $\mathbf{0 . 0}$ & 0.1 & $\mathbf{0 . 0}$ & 0.2 & 0.1 & $\mathbf{0 . 0}$ \\
\hline Non-commercial & 14.33 & 9.06 & 14.06 & 13.33 & 23.33 & 13.39 & 12.94 \\
\hline commercial & 21.10 & 22.74 & 21.19 & 21.41 & 18.31 & 21.40 & 21.53 \\
\hline
\end{tabular}




\subsubsection{The Impact of Bank Exposure}

In respect of the bank exposure it can be realized that the only disclosure index that makes a significant difference between highly exposed bank and less exposed bank is the COMMINDEX. This result indicates that highly exposed banks have higher community disclosure compared with their peers, other than that there is no significant difference between both groups of banks.

Table 9. Nonparametric statistics of bank Exposure

\begin{tabular}{lccccccc}
\hline CSR indices & $\begin{array}{c}\text { EMP } \\
\text { INDEX }\end{array}$ & $\begin{array}{c}\text { ENV } \\
\text { INDEX }\end{array}$ & $\begin{array}{c}\text { COMM } \\
\text { INDEX }\end{array}$ & $\begin{array}{c}\text { CUST } \\
\text { INDEX }\end{array}$ & $\begin{array}{c}\text { ISLAM } \\
\text { ICINDEX }\end{array}$ & $\begin{array}{c}\text { CSRQUAN } \\
\text { INDEX }\end{array}$ & $\begin{array}{c}\text { CSRQUA L } \\
\text { INDEX }\end{array}$ \\
\hline Mann-Whitney U & 142.0 & 149.5 & 92.0 & 120.5 & 137.5 & 131.5 & 135.5 \\
\hline Wilcoxon W & 220.0 & 500.5 & 443.0 & 471.5 & 215.5 & 482.5 & 486.5 \\
\hline$Z$ & -0.5 & -0.2 & -2.0 & -1.2 & -0.6 & -0.8 & -0.6 \\
\hline Sig. (2-tailed) & 0.6 & 0.8 & $\mathbf{0 . 0}$ & 0.2 & 0.5 & 0.4 & 0.5 \\
\hline Banks with low exposure & 18.33 & 20.04 & 24.83 & 22.46 & 17.96 & 21.54 & 21.21 \\
\hline Banks with high exposure & 20.04 & 19.25 & 17.04 & 18.13 & 20.21 & 18.56 & 18.71 \\
\hline
\end{tabular}

\section{Discussion and Conclusion}

This study seeks to empirically identify the most powerful stakeholders who shape and dominate the CSR disclosure in the banking sector, in Egypt. As explained earlier in this paper, the CSR disclosure has become a controversial issue which is largely structured and affected by the institutional environment. The development in the CSR disclosure was not identical across countries. Some countries have shown great improvements such as Australia and India (Ameeta et al., 2015); German (Relano \& Paulet, 2012); USA (Charles et al., 2014); New Zealand (Dobbs \& Staden, 2016). On the other hand, others are still striving to advance their disclosure such as Libya (John \& Adel Abdulhamid, 2009); Romania (Mocan et al., 2015); Malaysia (Abdifatah Ahmed, 2013); Malawi (Lipunga, 2013); Croatia (Hernaus \& Stojanovic, 2015); Bangladesh (Md. Hafij \& Mohammad Afjalur, 2015) as well as Egypt (Rizk et al., 2008; Hussainey et al., 2011; Soliman et al., 2013; Arafa \& ElHawary, 2017). The Egyptian government in collaboration with the Egyptian Stock Exchange (EGX) endeavor to encourage the adoption of the CSR. They constantly exert efforts to raise the awareness about the essentiality of the CSR adoption for the Egyptian community. Some Egyptian banks have followed such initiatives (i.e Bank Misr), meanwhile others still lagging behind. The empirical results spotted little improvement in the the CSR disclosure by non-Egyptian banks operating in Egypt during 2015. The unstable political condition since the revolution of 2011 has adversely affected many industry sectors which contributed in suspending the progress in the CSR disclosure. In general, our findings are consistent with prior studies conducted in similar developing countries such as Bangladesh, UAE, Lebanon and Poland.

In consistency with our prior expectations, the empirical results show that foreign banks have provided better CSR disclosure especially in the Environment and Employees indices. This may be due to the differences in the institutional environments where these banks have originally established (Branco \& Rodrigues, 2006, Md Habib Uz - Zaman et al., 2009, Brammer et al., 2012, Young \& Thyil, 2014). It also indicates that foreign banks are subject to supervision from their headquarters that intrinsically compel them to comply with the disclosure rules as in their home countries. According to Michelon et al.(2015) majority research has referred to corporate legitimacy while justifying the adoption of CSR. It is argued that organizations used to align their strategies and processes with pre-identified social norms to maintain their legitimacy.

Other bank attributes have positively affected the CSR disclosure such as being listed on the EGX, being a commercial bank, in addition to being non-governmental owned bank. Such banks are more exposed to the public pressure which makes them eager to enhance their CSR disclosure to meet the public expectations. This requires further research to study the impact of bank attributes on the quality and quantity aspects of the CSR disclosure in different jurisdictions. Predictive models may also be developed to anticipate the CSR disclosure for a given group of banks. Professional institutions and standard settlers may benefit from such studies in developing distinctive rules for regulated industries.

Moreover, the CSR disclosure by Islamic banks was generally low. However, this finding may not be generalizable as three Islamic banks have only been investigated due to the limited number of Islamic banks in the entire population. Nevertheless, our results are consistent with Mallin et al. (2014) who examined the CSR disclosure by 90 Islamic banks in 13 countries and found positive relationship between CSR disclosure and the financial performance 
of the banks. However, it is noticed that the CSR disclosure was relatively low, though AAOIFI Standard No.7 provides a template for Islamic banks which instructs them how to disclose their CSR. Our findings are also consistent with Faizah et al. (2018) who spotted a low level of environmental index. Accordingly, more studies are needed to examine the impact of Islamic banking system on the CSR disclosure and practices. Other control variables such as auditors' firm type, audit committee size and capital adequacy showed a positive impact on the CSR disclosure.

In terms of the qualitative aspects, of the CSR disclosure ranges from low to medium and has only been affected by the audit committee size and capital adequacy as a proxy of the leverage ratio.This implies that audit committee may encourage banks to improve their CSR quality by reviewing and editing this type of disclosure.

In respect of the sub-indices such as being listed on EGX has significantly and positively affected both the Customer and product index as well as the Islamic index. Bank specialty has also affected the Environmental index implying that commercial banks are more concern about environmental issues. Unlike previous research, the bank exposure has no dominant effect as it has affected the Community index only. Auditors' firm type has also affected two indices; Environment and Customer and Product. Meanwhile, the independent directors, foreign ownership and profitability have no significant effect in most cases. The government ownership has a positive impact on Customer and Product as well as Islamic indices. The non-parametric test has also provided supporting evidence and showed that listed banks provide better disclosure compared to non-listed banks. This result was expected, yet the difference was not significant. It is also recognized that non-governmental banks perform better than governmental banks. Simialrly, foreign banks have surpassed Egyptian banks in terms of the Employees and Environment indices. This reflect the powerful regulative environment where these banks are originated.

In brief, our results confirm that being listed on the Egyptian Stock Exchange, having audit committee or being audited by one of the big audit firms are the most powerful factors affecting the CSR disclosure by banks in the Egyptian context. It is striking that though foreign banks' disclosure was generally high, it was not at the same quality of their headquarters. This was realized by examining and comparing the disclosure of the website devoted for Egyp branch and the main website of the headquarter. The researchers have also realized that not all banks have a separate department for CSR which may justify the noticeable weakeness in the CSR disclosure. Though the generated results are largely consistent with prior studies, the results are confined to some limitations. The paucity of the examined population of banks (38) may affect the significance of some statistical measures. Therefore, it is suggested to enlarge the sample to include other institutions such as insurance companies and financial intermediaries in the future studies. Qualitative studies are also required to uncover the rationality beyond the CSR disclosure and to better understand the bank managers' perception and attitudes towards this type of disclosure. Furthermore, unweighted indices are used which inherently posits that all CSR contents are at an equal level of importance to all banks. Such postulate may lead to misleading results. Thus, it is recommended to use weighted indices in the future research while assessing the CSR disclosure by the financial sector.

\section{Acknowledgments}

The researchers would like to express their appreciation to the library at the British University in Egypt (BUE) to provide the databases that have been used in this paper (i.e. Thomson Reuters and Bank scope). They are also grateful to the reviewers and the editor for their constructive comments which helped them enhance the quality of this paper to a great extent.

The two authors have cooperated equally in writing this paper and conducting the empirical study.

\section{References}

Abdifatah, A. H. (2013). Corporate social responsibility disclosures over time: evidence from Malaysia. Managerial Auditing Journal, 28, 647-676. https://doi.org/10.1108/MAJ-07-2012-0729

Abdul Hamid, F.Z. (2004). Corporate social disclosure by banks and finance companies: Malaysian evidence. Corporate Ownership and Control, 1(4), 118-129.

Akano A Y, Jamiu O, Yaya.O A., \& Oluwalogbon O T. (2013). Corporate social responsibility activities disclosure by commercial banks in Nigeria. European Journal of Business and Management, 5(7), 173-185

Alotaibi, K., \& Hussainey, K. (2016a). The Determinants of CSR Disclosure Quantity and Quality: Evidence from Non-Financial Listed Firms in Saudi Arabia", International Journal of Disclosure and Governance. November 2016, 13(4), 364-393. https://doi.org/10.1057/jdg.2016.2

Alotaibi, K., \& Hussainey, K. (2016b). Quantity versus quality: The value relevance of CSR disclosure of Saudi 
companies. Corporate Ownership and Control, 13(2). https://doi.org/10.22495/cocv13i2p15

Ameeta, J., Monica, K., \& Dianne, T. (2015). Voluntary CSR disclosure works! Evidence from Asia-Pacific banks. Social Responsibility Journal, 11, 2-18. https://doi.org/10.1108/SRJ-10-2012-0136

Andrikopoulos, A., Samitas, A., \& M. Bekiaris (2014). Corporate social responsibility reporting in financial institutions: Evidence from Euronext. Research in International Business and Finance 32, 27-35. https://doi.org/10.1016/j.ribaf.2014.02.001

Arafa, I., \& ElHawary, E. (2017). Measuring and Evaluating the Corporate Social Responsibility Reporting by the banking sector in Egypt. Egyptian Accounting Review 6, Cairo University, in press.

Babío Arcay, M. R., \& Muiño Vázquez, M. F. (2005). Corporate Characteristics, Governance Rules and the Extent of Voluntary Disclosure in Spain. Advances in Accounting, incorporating Advances in International Accounting, 21, 299-331. https://doi.org/10.1016/S0882-6110(05)21013-1

Bello, H., \& Meka, E. (2014). Auditing Of Corporate Social Responsibility (Case Study - Albanian Banking Sector). Journal of Academic Research in Economics, 6(1), 150-167.

Bonsón, E., \& Bednárová, M. (2015). CSR reporting practices of Eurozone companies. Revista de Contabilidad, 18(2), 182-193. https://doi.org/10.1016/j.rcsar.2014.06.002

Boubakri, N., Ghoul, S. El, Wang, H., Guedhami, O., \& Kwok, C. C. Y. (2016). Cross-listing and corporate social responsibility. Journal of Corporate Finance, 41, 123-138. https://doi.org/10.1016/j.jcorpfin.2016.08.008

Brammer, S., Jackson, G. \& Matten, D. 2012. Corporate Social Responsibility and institutional theory: new perspectives on private governance. Socio-Economic Review, 10, 3-28. https://doi.org/10.1093/ser/mwr030

Branco, M. C., \& Rodrigues, L. L. (2006). Communication of corporate social responsibility by Portuguese banks: A legitimacy theory perspective. Corporate Communications: An International Journal, 11(3), 232-248. https://doi.org/10.1108/13563280610680821

Branco M. C, \& Rodrigues L. L, (2008). Social responsibility disclosure: a study of proxies for the public visibility of Portuguese banks. The British Accounting Review, 40(2), 161-181. https://doi.org/10.1016/j.bar.2008.02.004

Chakroun, R., \& Hussainey, K. (2014). Disclosure quality in Tunisian annual reports. Corporate Ownership and Control, 11(4),58-80. https://doi.org/10.22495/cocv11i4p5

Chan, M. C., Watson, J. ,\& Woodliff, D. (2014). Corporate Governance Quality and CSR Disclosures. Journal of Business Ethics, 125(1), 59-73. https://doi.org/10.1007/s10551-013-1887-8

Charles, H. C., Michelon, G., Dennis, M. P. ,\& W. R. Robin. (2014). CSR report assurance in the USA: an empirical investigation of determinants and effects. Sustainability Accounting, Management and Policy Journal, 130.

Chen, L., Bin, S., Albert, T. ,\& Wei, Y. (2016). Audited Financial Reporting and Voluntary Disclosure of Corporate Social Responsibility (CSR) Reports. Journal of Management Accounting Research, 28(2), 53-76. https://doi.org/10.2308/jmar-51411

Darus, F., Mad, S. ,\& Yusoff, H. (2014). The Importance of Ownership Monitoring and Firm Resources on Corporate Social Responsibility (CSR) of Financial Institutions. Procedia - Social and Behavioral Sciences, 145, 173-180.

Darus, F., S. Mad and H. Yusoff (2014). "The Importance of Ownership Monitoring and Firm Resources on Corporate Social Responsibility (CSR) of Financial Institutions." Procedia - Social and Behavioral Sciences, 145, 173-180. https://doi.org/10.1016/j.sbspro.2014.06.024

De Villiers, C. ,\& Alexander, D. (2014).The institutionalisation of corporate social responsibility reporting. The British Accounting Review, 46(2), 198-212. https://doi.org/10.1016/j.bar.2014.03.001

Deegan, C. (2002). The legitimizing effect of social and environmental disclosures: A theoretical foundation. Accounting, Auditing and Accountability Journal, 15(3), 282-311. https://doi.org/10.1108/09513570210435852

Dobbs, S., \& Staden, C. V. ( 2016). Motivations for corporate social and environmental reporting: New Zealand evidence. Sustainability Accounting, Management and Policy Journal, 7, 449-472.

Douglas A, Doris J \& Johnson B, (2004). Corporate social reporting in Irish financial institutions,. The TQM Magazine, 16(6), 387 - 395. https://doi.org/10.1108/09544780410563301

El Kayaly, D. (2014). Corporate Social Responsibility supporting SMEs: Lessons Learned from Egypt. Working Paper No. 2014/25. The Maastricht School of Management. 
Fatma, M. ,\& Z. Rahman. (2016). The CSR's influence on customer responses in Indian banking sector. Journal of Retailing and Consumer Services, 29, 49-57. https://doi.org/10.1016/j.jretconser.2015.11.008

Faizah, D., Haslinda, Y., Dayang Milianna Abang, N., Azlan, A. \& Hasan, F. (2018). Corporate Social Responsibility Practices of Malaysian Islamic Banks from the Shariah Perspective: A Focus on the Key Dimensions. Global Journal Al-Thaqafah, 8(1), 41-55 (2018), 41. https://doi.org/10.7187/GJATSI2018-03

Fernandez-Feijoo, B., Romero, S. , \& Ruiz, S. (2014). Commitment to Corporate social responsibility measured through global reporting initiative reporting: factors affecting the behavior of companies. Journal of Cleaner Production, 81, 244-254. https://doi.org/10.1016/j.jclepro.2014.06.034

Freeman, R. E. (1984). Strategic management: A stakeholder approach. Boston: Pitman.

Fuente, J. A., García-Sánchez, I. M. , \& Lozano M. B. (2017). The role of the board of directors in the adoption of GRI guidelines for the disclosure of CSR information. Journal of Cleaner Production, 141, 737-750. https://doi.org/10.1016/j.jclepro.2016.09.155

Giannarakis, G. (2014). Corporate governance and financial characteristic effects on the extent of corporate social responsibility disclosure. Social Responsibility Journal, https://doi.org/10.1108/SRJ-02-2013-0008

Global Reporting Initiative (GRI). (2014). Sustainability Reporting Guidelines 3. Reporting Principles and Disclosure Standards. Available at: http://www.globalreporting.org.

Gunawan, J. (2015). Corporate social disclosures in Indonesia: stakeholders' influence and motivation. Social Responsibility Journal, 11(3), 535. https://doi.org/10.1108/SRJ-04-2014-0048

Habbash, M. (2016). Corporate governance and corporate social responsibility disclosure: evidence from Saudi Arabia. Social Responsibility Journal, 12(4), 740-754. https://doi.org/10.1108/SRJ-07-2015-0088

Habib - Uz - Zaman, K. (2010). The effect of corporate governance elements on corporate social responsibility (CSR) reporting: Empirical evidence from private commercial banks of Bangladesh. International Journal of Law and Management, 52(2), 82-109.

Haniffa, R. M. ,\& Cooke, T. E.. (2005). The impact of culture and governance on corporate social reporting. Journal of Accounting and Public Policy, 24, 391-430. https://doi.org/10.1016/j.jaccpubpol.2005.06.001

Hassan, O. ,\& Marston, C., (2010). Disclosure measurement in the empirical accounting literature: a review article', working paper, Economics and Finance', Working Paper Series, Brunel University, available at: http://www.brunel.ac.uk/about/acad/sss/depts/economics.

Hassanein, A.,,\& Hussainey, K., (2015). Is forward-looking financial disclosure really informative? Evidence from UK narrative statements. International Review of Financial Analysis, 41, 52-61. https://doi.org/10.1016/j.irfa.2015.05.025

Hasseldine, J., Salama, A. ,\& Toms, S. (2005). Quantity versus Quality:The Impact of Environmental Disclosures on the reputations of UK plcs. British Accounting Review, 37(2), 231-248. https://doi.org/10.1016/j.bar.2004.10.003

Hernaus, A. I.,\& Stojanovic, A. (2015). Determinants of Bank Social Responsibility: Case of Croatia. Ekonomie a Management, 18(2), 117-134. https://doi.org/10.15240/tul/001/2015-2-009

Hu, V.-i. \& Scholtens, B. (2014). Corporate Social Responsibility Policies of Commercial Banks in Developing Countries. Sustainable Development, 22(4), 276-288. https://doi.org/10.1002/sd.1551

Hussainey, K., Elsayed, M. \& Razik, M. A. (2011), Factors affecting corporate social responsibility disclosure in Egypt. Corporate Ownership and Control Journal, 8, 432-443. https://doi.org/10.22495/cocv8i4c4art5

Jain, A., Keneley, M. „\& Thomson, D. (2015). Voluntary CSR disclosure works! Evidence from Asia-Pacific banks. Social Responsibility Journal, 11(1), 2-18. https://doi.org/10.1108/SRJ-10-2012-0136

Jizi, M., Salama, A., Dixon, R. , \& Stratling, R. (2014). Corporate Governance and Corporate Social Responsibility Disclosure: Evidence from the US Banking Sector. Springer Science \& Business Media B.V. 125: 601-615. https://doi.org/10.1007/s10551-013-1929-2

John, D. P. \& Adel Abdulhamid, M. (2009), Corporate social disclosure in Libya. Social Responsibility Journal, (5), 311-327. 
Kansal, M., Joshi, M. , \& Batra, G. S. (2014). Determinants of corporate social responsibility disclosures: Evidence from India. Advances in Accounting, 30(1), 217-229. https://doi.org/10.1016/j.adiac.2014.03.009

Khan, H. U. Z., Halabi, A. K. ,\& Samy, M. (2009). Corporate social responsibility (CSR) reporting: a study of selected banking companies in Bangladesh. Social Responsibility Journal, 5(3), 344-357. https://doi.org/10.1108/17471110910977276

Khan, A., Muttakin, M. ,\& Siddiqui, J. (2013). Corporate Governance and Corporate Social Responsibility Disclosures: Evidence from an Emerging Economy. Journal of Business Ethics, 114(2), 207-223. https://doi.org/10.1007/s10551-012-1336-0

Khemir, S. ,\& Baccouche, C, (2010). Analysis of the determinants of corporate social responsibility disclosure in the annual reports of Tunisian listed firms. Research in Accounting in Emerging Economies, 10, 119-144. https://doi.org/10.1108/S1479-3563(2010)0000010010

Lipunga, A. M. (2013). Corporate social responsibility reporting by commercial banks in annual reports: evidence from Malawi. International Journal of Business and Social Research, 3(9), 88-101.

Mallin, C., Farag, H. ,\& Ow-Yong, K. (2014). Corporate social responsibility and financial performance in Islamic banks. Journal of Economic Behavior \& Organization, 103, S21-S38. https://doi.org/10.1016/j.jebo.2014.03.001

McGuinness, P. B., Vieito, J. P. ,\& Wang, M. (2017). The role of board gender and foreign ownership in the CSR performance of Chinese listed firms. Journal of Corporate Finance, 42, 75-99. https://doi.org/10.1016/j.jcorpfin.2016.11.001

Md Habib - Uz - Zaman, K., Abdel, K. H. ,\& Martin, S. (2009). Corporate social responsibility (CSR) reporting: a study of selected banking companies in Bangladesh. Social Responsibility Journal, 5, 344-357. https://doi.org/10.1108/17471110910977276

Md. Hafij, U. ,\& Mohammad Afjalur, R. (2015). Corporate social responsibility reporting practices in banking companies in Bangladesh : Impact of regulatory change. Journal of Financial Reporting and Accounting, 200.

Merve, K. (2016). Online corporate social responsibility (CSR) disclosure in the banking industry: Evidence from Turkey. International Journal of Bank Marketing, 34(4), 550-569. https://doi.org/10.1108/IJBM-04-2015-0060

Metaxas, T. ,\& Tsavdaridou, M. (2010). Corporate Social Responsibility in Europe: Denmark, Hungary and Greece. Journal of Contemporary European Studies, 18(1), 25-46. https://doi.org/10.1080/14782801003638679

Michelon, G., Pilonato S. ,\& Ricceri F. (2015). CSR reporting practices and the quality of disclosure: An empirical analysis. Critical Perspectives on Accounting, 33, 59-78. https://doi.org/10.1016/j.cpa.2014.10.003

Mocan, M., Rus, S., Draghici, A., Ivascu, L. ,\& Turi, A. (2015). Impact of Corporate Social Responsibility Practices on the Banking Industry in Romania. Procedia Economics and Finance, 23, 712-716. https://doi.org/10.1016/S2212-5671(15)00473-6

Mohamed, C. K. (2017). The determinants of corporate voluntary disclosure policy: Evidence from the Abu Dhabi Securities Exchange (ADX). Journal of Accounting in Emerging Economies, 7(2), 249-265. https://doi.org/10.1108/JAEE-12-2015-0089

Moir, L. (2001). What do we mean by corporate social responsibility? Corporate Governance: The international journal of business in society, 1(2), 16-22. https://doi.org/10.1108/EUM0000000005486

Muttakin, M. B., \& Khan, A. (2014). Determinants of corporate social disclosure: Empirical evidence from Bangladesh. Advances in Accounting, 30(1), 168-175. https://doi.org/10.1016/j.adiac.2014.03.005

Nan, S., Aly, S., Khaled, H , \& Murya, H. (2010). Corporate environmental disclosure, corporate governance and $\begin{array}{llll}\text { earnings management. } & \text { Managerial }\end{array}$ https://doi.org/10.1108/02686901011061351

Ortas, E., Álvarez, I., Jaussaud, J., \& Garayar, A. (2015). The impact of institutional and social context on corporate environmental, social and governance performance of companies committed to voluntary corporate social responsibility initiatives. Journal of Cleaner Production, 108, Part A: 673-684.

Phillips, R.A., Freeman, E., \& Wicks, A.C. (2003), What stakeholder theory is not. Business Ethics Quarterly, 13(1), 479-502. https://doi.org/10.5840/beq200313434

Preuss, L., Barkemeyer, R., \& Glavas, A. (2016). Corporate Social Responsibility in Developing Country 
Multinationals: Identifying Company and Country-Level Influences. Business Ethics Quarterly, 26(3), 347-378. https://doi.org/10.1017/beq.2016.42

Raida, C., Hamadi, M., \& Sarra, M. (2017). Determinants of CSR disclosure of Tunisian listed banks: a multi-support analysis. Social Responsibility Journal, 13(3), 552-584. https://doi.org/10.1108/SRJ-04-2016-0055

Rajalakshmi, S. (2016). Sustainable development through environmental ethics. International Journal of Applied Research, 2(3), 464-467.

Relano, F., \& Paulet, E. ( 2012). Corporate responsibility in the banking sector: a proposed typology for the German case. International Journal of Law and Management, 54, 379-393. https://doi.org/10.1108/17542431211264269

Robinson, J. (2004). Squaring the circle? Some thoughts on the idea of sustainable development. Ecological Economics, 48, 369-384. https://doi.org/10.1016/j.ecolecon.2003.10.017

Rizk, R., Dixon, R., \& Woodhead, A. (2008) Corporate social and environmental reporting: a survey of disclosure practices in Egypt. Social Responsibility Journal, 4, 306-323. https://doi.org/10.1108/17471110810892839

Rudyanto, A., \& Siregar, S. V. (2018). The effect of stakeholder pressure and corporate governance on the sustainability report quality. International Journal of Ethics and Systems, 34(2), 233-249. https://doi.org/10.1108/IJOES-05-2017-0071

Said, R., Zainuddin, Y. H., \& Haron, H. (2009). The relationship between corporate social responsibility disclosure and corporate governance characteristics in Malaysian public listed companies. Social Responsibility Journal, 5(2), 212. https://doi.org/10.1108/17471110910964496

Sharif, M., \& Rashid, K. (2014). Corporate governance and corporate social responsibility (CSR) reporting: an empirical evidence from commercial banks (CB) of Pakistan. Quality \& Quantity, 48(5), 2501-2521. https://doi.org/10.1007/s11135-013-9903-8

Sobhani, F. A., Amran, A,. \& Zainuddin, Y. (2012). Sustainability disclosure in annual reports and websites: a study of the banking industry in Bangladesh. Journal of Cleaner Production, 23(1), 75-85. https://doi.org/10.1016/j.jclepro.2011.09.023

Soliman, M., El Din, M. \& Sakr, A. (2013). Ownership structure and Corporate Social Responsibility (CSR): An empirical study of the listed companies in Egypt. https://doi.org/10.2139/ssrn.2257816

Sul, W., Choi, H. M. \& Quan, R. S. (2014). Shareholder Conflict as a Determinant of Corporate Social Responsibility Commitment for Shared Growth. Emerging Markets Finance and Trade, 50(5), 97-110.

Ullah, M. H. \& Rahman, M. A. (2015). Corporate social responsibility reporting practices in banking companies in Bangladesh: Impact of regulatory change. Journal of Financial Reporting and Accounting, 13(2), 200-225. https://doi.org/10.1108/JFRA-05-2013-0038

Viveros, H. (2017). Unpacking stakeholder mechanisms to influence corporate social responsibility in the mining sector. Resources Policy, 51, 1-12. https://doi.org/10.1016/j.resourpol.2016.10.014

Yeh, C.-C., Kuo, L., \& Yu, H.-C. (2011). Disclosure of Corporate Social Responsibility and Value Creation: Evidence from China. Transnational Corporations Review, 3(3), 34-50. https://doi.org/10.1080/19186444.2011.11658295

Young, S. \& Thyil, V. (2014). Corporate Social Responsibility and Corporate Governance: Role of Context in International Settings. Journal of Business Ethics, 122, 1-24. https://doi.org/10.1007/s10551-013-1745-8

Yu, Y. \& Choi, Y. (2016). Stakeholder pressure and CSR adoption: The mediating role of organizational culture for Chinese companies. The Social Science Journal, 53(2), 226-235. https://doi.org/10.1016/j.soscij.2014.07.006

Zsolnai, L. (2011). Environmental ethics for business sustainability. International Journal of Social Economics, 38(11), 892 -899. https://doi.org/10.1108/03068291111171397 
Appendix (1)

\begin{tabular}{|c|c|c|}
\hline The type of variables & Variable Code & Variable measure \\
\hline \multicolumn{3}{|l|}{ Dependent Variables } \\
\hline Total CSR quantitative index & CSR_QUALINDEX & Total observations to total items constituting the index \\
\hline Total CSR Quality index & CSR_QUANINDEX & Total observations to total items constituting the index \\
\hline Employees Index & EMPL_INDEX & Total observations to total items constituting the index \\
\hline Environment Index & ENVI-INDEX & Total observations to total items constituting the index \\
\hline Community Index & COMM-INDEX & Total observations to total items constituting the index \\
\hline Customer and Product Index & CUST-INDEX & Total observations to total items constituting the index \\
\hline Islamic activities Index & ISIAMIC-INDEX & Total observations to total items constituting the index \\
\hline \multicolumn{3}{|l|}{ Independent variables } \\
\hline LIST_STATUS & H1: X1 & Dichotomous; 1 if the bank is listed on EGX, and 0 if otherwise. \\
\hline B-SPECIALITY & $\mathrm{H} 2: \mathrm{X} 2$ & Dichotomous; 1 if the bank is commercial, and 0-if otherwise. \\
\hline B-EXPOSURE & H3: X3 & $\begin{array}{l}\text { Dichotomous; } 1 \text { if the bank is largely exposes (possessing more than } 60 \\
\text { branches) and } 0 \text {, if otherwise. }\end{array}$ \\
\hline AUDIT-TYPE & $\mathrm{H} 4: \mathrm{X} 4$ & Dichotomous; 1 if the audit firm is " 1 " of the big 4 , and 0 , if otherwise \\
\hline Governance: PINDDIER & H5: X5 & Number of independent directors to total number of directors \\
\hline Governance: AUDITCOMM & X6: X6 & Number of independent directors on the audit committee \\
\hline Ownership: GOVE-RATIO & H7: $\mathrm{X} 7$ & $\begin{array}{l}\text { Percentage of shares owned by government (Egyptian or non -Egyptian) and } \\
\text { as dichotomous; } 1 \text { if totally owned by government is " } 1 \text { " and } 0 \text {, if otherwise }\end{array}$ \\
\hline Ownership FOREIN-RATIO & $\mathrm{X} 8 \mathrm{a} \& \mathrm{X} 8 \mathrm{~b}$ & total percentage of shares owned by foreign or Arabic investor \\
\hline \multicolumn{3}{|l|}{ Control variables: } \\
\hline Bank size: T-ASSETS & X9 & Natural log of total assets \\
\hline Profitability: ROAE & $\mathrm{X} 10$ & Return on Assets \\
\hline $\begin{array}{l}\text { TIER ONE LEVERAGE: } \\
\text { LEVERAGE }\end{array}$ & $\mathrm{X} 11$ & Tier one capital to average total risky assets \\
\hline
\end{tabular}




\section{Appendix (2)}

\section{The CSR Quantity index}

\begin{tabular}{|c|c|c|}
\hline & Banks & $\%$ \\
\hline \multicolumn{3}{|l|}{ Employee index } \\
\hline Employee Data & 19 & $50.00 \%$ \\
\hline Training and Development and rotation programs & 23 & $60.53 \%$ \\
\hline Employee health and safety (medical coverage) & 21 & $55.26 \%$ \\
\hline Employees Benefits (scholarship funds, house loans, education loan & 16 & $42.11 \%$ \\
\hline Employees Human rights (ethical codes and principles, diversity, employees syndicate, employee's relation unit) & 16 & $42.11 \%$ \\
\hline Employees' Pension funds & 16 & $42.11 \%$ \\
\hline $\begin{array}{l}\text { Internal Culture (internal communication as monthly bulletins and mailing, sports and social committee, } \\
\text { communication day, annual meetings, casual day, volunteering programs) }\end{array}$ & 16 & $42.11 \%$ \\
\hline \multicolumn{3}{|l|}{ Environmental index } \\
\hline Environmental policy statement, systems and audit & 20 & $52.63 \%$ \\
\hline Designing facilities harmonious with environment & 16 & $42.11 \%$ \\
\hline Conservation of natural resources and Using recycling material and reductions achieved & 17 & $44.74 \%$ \\
\hline Sponsoring environmental activities & 18 & $47.37 \%$ \\
\hline Lending and investment policies & 9 & $23.68 \%$ \\
\hline Waste management & 16 & $42.11 \%$ \\
\hline Financial implication related to climate change & 13 & $34.21 \%$ \\
\hline \multicolumn{3}{|l|}{ Community index } \\
\hline Community investment & 34 & $89.47 \%$ \\
\hline Contribution to national economy & 28 & $73.68 \%$ \\
\hline Support for Education & 29 & $76.32 \%$ \\
\hline Support for public Health & 25 & $65.79 \%$ \\
\hline Social Loan & 22 & $57.89 \%$ \\
\hline Social activities support & 28 & $73.68 \%$ \\
\hline Funding scholarship programs & 15 & $39.47 \%$ \\
\hline Charity and Donation & 29 & $76.32 \%$ \\
\hline volunteering & 18 & $47.37 \%$ \\
\hline Establish non-profit project & 15 & $39.47 \%$ \\
\hline Support for Art and culture & 20 & $52.63 \%$ \\
\hline Sponsoring sports & 16 & $42.11 \%$ \\
\hline \multicolumn{3}{|l|}{ Customer and products } \\
\hline Developing and innovating new products & 33 & $86.84 \%$ \\
\hline Products and services quality & 36 & $94.74 \%$ \\
\hline Advertising & 29 & $76.32 \%$ \\
\hline Meeting customer needs (periodic statements, internet and corporate websites, branches and auto branches) & 33 & $86.84 \%$ \\
\hline customer satisfaction and complaints & 33 & $86.84 \%$ \\
\hline Customer service and call centers & 31 & $81.58 \%$ \\
\hline Customer satisfaction & 32 & $84.21 \%$ \\
\hline Service for disabled, aged and difficult to reach customers & 17 & $44.74 \%$ \\
\hline
\end{tabular}




\begin{tabular}{|l|c|}
\hline Islamic Activities & 3 \\
\hline Charitable society for the holy Quran memorization holly & $7.89 \%$ \\
\hline Ongoing charity ( WAGFF) & $15.79 \%$ \\
\hline Hajj donations & $0.00 \%$ \\
\hline Other disclosure related to Sharia activities & $36.84 \%$ \\
\hline Earnings and expenditure prohibited by sharia & 14 \\
\hline Late repayments and insolvent clients and avoiding onerous terms & 16 \\
\hline Qard Hasan & $42.11 \%$ \\
\hline Screening and informing clients for compliance with Islamic principles & $15.79 \%$ \\
\hline Zakat & $10.53 \%$ \\
\hline Waaf management & 4 \\
\hline
\end{tabular}

Appendix 3 The CSR Quality index

\begin{tabular}{|c|c|c|c|}
\hline \multicolumn{4}{|c|}{ Clarity } \\
\hline Code & Question & measure & Literature \\
\hline \multirow[t]{5}{*}{ CL1 } & \multirow{5}{*}{$\begin{array}{l}\text { To what extent does } \\
\text { the bank disclose the } \\
\text { CSR in the annual } \\
\text { report (report scope)? } \\
\text { (defining CSR } \\
\text { strategy objectives, } \\
\text { goals and } \\
\text { achievements) }\end{array}$} & $0=$ No disclosed CSR information & \multirow{5}{*}{$\begin{array}{l}\text { Alotaibi and } \\
\text { Hussainey, } 2016 \\
\text { Chakroun et al. } \\
2017 \\
\text { GRI, } 2013\end{array}$} \\
\hline & & $\begin{array}{l}\text { 1- Limited Disclosed CSR information (A paragraph or few } \\
\text { sentences in the annual report, only the mandatory } \\
\text { disclosure requirements) }\end{array}$ & \\
\hline & & $\begin{array}{l}2=\text { A part as a subsection of the annual report with a } \\
\text { headline of CSR. }\end{array}$ & \\
\hline & & $3=$ Extensive CSR information (A chapter) & \\
\hline & & $\begin{array}{l}4=\text { CSR in annual report and a separate report on the } \\
\text { website. }\end{array}$ & \\
\hline \multirow[t]{5}{*}{ CL2 } & \multirow{5}{*}{$\begin{array}{l}\text { To what extent does } \\
\text { the bank disclose the } \\
\text { CSR on its website? } \\
\text { (in terms of defining } \\
\text { CSR strategy } \\
\text { objectives, goals and } \\
\text { achievements) }\end{array}$} & $0=$ No disclosed CSR information & \multirow{4}{*}{$\begin{array}{l}\text { Alotaibi and } \\
\text { Hussainey, } 2016 \\
\text { Chakroun et al. } \\
2017 \\
\text { GRI, } 2013\end{array}$} \\
\hline & & $\begin{array}{l}\text { 1- Limited Disclosed CSR information (A paragraph with } \\
\text { photos as a part of another headline mentioned on the page). }\end{array}$ & \\
\hline & & $2=$ Just one page with a headline of CSR & \\
\hline & & $\begin{array}{l}3=\text { Extensive CSR information (more than one page (or } \\
\text { links) on the web with photos and headline of CSR) }\end{array}$ & \\
\hline & & $\begin{array}{l}4=\text { Upload separate CSR report with some information on } \\
\text { the web }\end{array}$ & \\
\hline \multirow[t]{5}{*}{ CL3 } & \multirow{5}{*}{$\begin{array}{l}\text { To what extent does } \\
\text { the CSR information } \\
\text { in terms of CSR risks } \\
\text { and opportunities } \\
\text { management } \\
\text { contribute in meeting } \\
\text { the stakeholder's } \\
\text { expectations and } \\
\text { needs? (as applying } \\
\text { Equator principles). }\end{array}$} & $0=$ No CSR risk management information & $\begin{array}{l}\text { Alotaibi and } \\
\text { Hussainey, } 2016\end{array}$ \\
\hline & & $\begin{array}{l}1 \text { = Little CSR risk management, no useful for forming } \\
\text { expectations }\end{array}$ & \multirow{4}{*}{$\begin{array}{l}\text { Chakroun et al. } \\
2017 \\
\text { GRI, } 2013\end{array}$} \\
\hline & & $2=$ Useful CSR risk management information. & \\
\hline & & $\begin{array}{l}3=\text { Useful CSR risk management information, helpful for } \\
\text { developing expectations }\end{array}$ & \\
\hline & & $\begin{array}{l}4=\text { Additional CSR risk management information which } \\
\text { helps developing expectations (applying Equator principles) }\end{array}$ & \\
\hline
\end{tabular}




\begin{tabular}{|c|c|c|}
\hline \multirow[t]{5}{*}{ CL4 } & \multirow{5}{*}{$\begin{array}{l}\text { To what extent the } \\
\text { CSR information } \\
\text { provide the } \\
\text { stakeholders feedback } \\
\text { as to how the social } \\
\text { and environmental } \\
\text { events affected the } \\
\text { bank? }\end{array}$} & $0=$ No feedback \\
\hline & & $1=$ Little feedback on the past \\
\hline & & $2=$ Feedback in present \\
\hline & & $\begin{array}{l}3=\text { Feedback helps understanding how events and } \\
\text { transactions influenced the company }\end{array}$ \\
\hline & & 4 = Comprehensive feedback \\
\hline
\end{tabular}

Alotaibi and Hussainey, 2016

Chakroun et al. 2017

GRI, 2013

\section{Balance}

\begin{tabular}{|c|c|c|c|}
\hline \multirow{5}{*}{ B1 } & \multirow{5}{*}{$\begin{array}{l}\text { To what extent does } \\
\text { the bank, in the } \\
\text { discussion of CSR, } \\
\text { highlight the positive } \\
\text { and negative aspects } \\
\text { of CSR performance? }\end{array}$} & $0=$ No positive and negative aspects, are mentioned & \multirow{5}{*}{$\begin{array}{l}\text { Alotaibi and } \\
\text { Hussainey, } 2015 \\
\text { Chakroun et al. } \\
2017 \\
\text { GRI, } 2013\end{array}$} \\
\hline & & $1=$ Negative aspects only mentioned in footnotes & \\
\hline & & $2=$ Emphasize on positive aspects & \\
\hline & & $3=$ Balance positive/negative aspects of CSR & \\
\hline & & $\begin{array}{l}4=\text { Impact of positive/negative aspects of CSR is also } \\
\text { explained }\end{array}$ & \\
\hline \multirow[t]{5}{*}{$\mathrm{B} 2$} & \multirow{5}{*}{$\begin{array}{l}\text { To what extent does } \\
\text { the company provide } \\
\text { more description and } \\
\text { details of CSR } \\
\text { performance trends } \\
\text { on a year-to-year } \\
\text { basis? }\end{array}$} & $0=$ No description of CSR performance & \multirow{5}{*}{$\begin{array}{l}\text { Alotaibi and } \\
\text { Hussainey, } 2016 \\
\text { Chakroun et al. } \\
2017 \\
\text { GRI, } 2013\end{array}$} \\
\hline & & $\begin{array}{l}1 \text { = Information on CSR performance limited, not in a apart } \\
\text { subsection in the annual report, or a paragraph on the web } \\
\text { only }\end{array}$ & \\
\hline & & $\begin{array}{l}2=\text { Apart subsection of the annual report or subtitle on the } \\
\text { web }\end{array}$ & \\
\hline & & $\begin{array}{l}3=\text { Extra attention paid to information concerning CSR } \\
\text { performance on the web and in the annual report }\end{array}$ & \\
\hline & & $\begin{array}{l}4=\text { Comprehensive description of CSR performance in a } \\
\text { separate report }\end{array}$ & \\
\hline \multicolumn{4}{|c|}{ Accuracy } \\
\hline \multirow[t]{5}{*}{ A1 } & \multirow{5}{*}{$\begin{array}{l}\text { To what extent is the } \\
\text { annual report or the } \\
\text { website presented } \\
\text { CSR information in } \\
\text { accurate and } \\
\text { well-organized } \\
\text { manner? (the } \\
\text { reporting presentation } \\
\text { or design) }\end{array}$} & $\begin{array}{l}0=\text { Very bad presentation ( The CSR information is } \\
\text { missing) }\end{array}$ & $\begin{array}{l}\text { Alotaibi and } \\
\text { Hussainey, } 2016\end{array}$ \\
\hline & & $\begin{array}{l}1=\text { Bad presentation (text only) qualitative information } \\
\text { only, without an explanation. }\end{array}$ & \multirow{4}{*}{$\begin{array}{l}\text { Chakroun et al. } \\
2017 \\
\text { GRI, } 2013\end{array}$} \\
\hline & & $\begin{array}{l}2=\text { Poor presentation (text and photos) qualitative } \\
\text { information and provide some evidences. }\end{array}$ & \\
\hline & & $\begin{array}{l}3=\text { Good presentation (text, photos, graphs and ratio) } \\
\text { qualitative and quantitative information }\end{array}$ & \\
\hline & & $\begin{array}{l}4=\text { Very good presentation (full paragraph with more } \\
\text { descriptive) qualitatively and quantitatively information } \\
\text { with the evidence in figure or number. }\end{array}$ & \\
\hline \multirow[t]{5}{*}{$\mathrm{A} 2$} & \multirow{5}{*}{$\begin{array}{l}\text { To what extent does } \\
\text { the presence of } \\
\text { graphs, photos and } \\
\text { tables clarify the } \\
\text { presented CSR } \\
\text { information? (the } \\
\text { presence of } \\
\text { consolidated data) }\end{array}$} & $0=$ No graphs and photos & \multirow{5}{*}{$\begin{array}{l}\text { Alotaibi and } \\
\text { Hussainey, } 2016 \\
\text { Chakroun et al. } \\
2017 \\
\text { GRI, } 2013\end{array}$} \\
\hline & & $1=1-5$ graphs and photos & \\
\hline & & $2=6-10$ graphs and photos & \\
\hline & & $3=11-15$ graphs and photos & \\
\hline & & $4=>15$ graphs and photos & \\
\hline
\end{tabular}




\begin{tabular}{|c|c|c|c|}
\hline \multicolumn{4}{|c|}{ Comparability } \\
\hline \multirow[t]{5}{*}{$\mathrm{C} 1$} & \multirow{5}{*}{$\begin{array}{l}\text { To what extent is the } \\
\text { CSR information in } \\
\text { the annual report or } \\
\text { the website } \\
\text { comparable to } \\
\text { information provided } \\
\text { by other banks? }\end{array}$} & $0=$ No comparability ( no paragraph) & $\begin{array}{l}\text { Alotaibi and } \\
\text { Hussainey, } 2016\end{array}$ \\
\hline & & 1= Limited comparability (one paragraph) & $\begin{array}{l}\text { Chakroun et al. } \\
2017\end{array}$ \\
\hline & & $2=$ Moderate comparability (two paragraphs) & GRI, 2013 \\
\hline & & $\begin{array}{l}3=\text { Very much comparability (two paragraph with } \\
\text { numbering) }\end{array}$ & \\
\hline & & $4=$ Very extensive comparability (more than above) & \\
\hline \multirow[t]{5}{*}{$\mathrm{C} 2$} & \multirow{5}{*}{$\begin{array}{l}\text { To what extent does } \\
\text { the bank present } \\
\text { financial index } \\
\text { numbers and ratios of } \\
\text { CSR performance in } \\
\text { the annual report or } \\
\text { on the website? }\end{array}$} & $0=$ No ratios & \multirow{5}{*}{$\begin{array}{l}\text { Alotaibi and } \\
\text { Hussainey, } 2016 \\
\text { Chakroun et al. } \\
2017 \\
\text { GRI, } 2013\end{array}$} \\
\hline & & $1=1-2$ ratios & \\
\hline & & $2=3-5$ ratios & \\
\hline & & $3=6-10$ ratios & \\
\hline & & $4=>10$ ratios & \\
\hline \multirow[t]{5}{*}{$\mathrm{C} 3$} & \multirow{5}{*}{$\begin{array}{l}\text { To what extent is the } \\
\text { current year bank's } \\
\text { CSR performance in } \\
\text { the report comparable } \\
\text { to the previous year's } \\
\text { CSR performance? }\end{array}$} & $0=$ No comparison & \multirow{5}{*}{$\begin{array}{l}\text { Alotaibi and } \\
\text { Hussainey, } 2016 \\
\text { Chakroun et al. } \\
2017 \\
\text { GRI, } 2013\end{array}$} \\
\hline & & $1=$ Only with previous year & \\
\hline & & $2=$ With 3 years & \\
\hline & & $3=5$ years + description of implications & \\
\hline & & $4=10$ years + description of implications & \\
\hline \multicolumn{4}{|c|}{ Reliability } \\
\hline \multirow[t]{5}{*}{ RL1 } & \multirow{5}{*}{$\begin{array}{l}\text { To what extent does } \\
\text { the bank CSR } \\
\text { reporting follow } \\
\text { generally accepted } \\
\text { reporting guidelines } \\
\text { (standards) for } \\
\text { presenting the CSR } \\
\text { information? }\end{array}$} & $0=$ No guidelines followed & \multirow[t]{5}{*}{ GRI, 2013} \\
\hline & & $\begin{array}{l}1=\text { Few points of one generally accepted guidelines are } \\
\text { followed }\end{array}$ & \\
\hline & & $\begin{array}{l}2=\text { Most but not all the points of one generally accepted } \\
\text { guidelines }\end{array}$ & \\
\hline & & $\begin{array}{l}\text { 3=Follow Only one Generally accepted reporting } \\
\text { guidelines. (as GRI or UNGC, or AA1000, ISO 26000) }\end{array}$ & \\
\hline & & $\begin{array}{l}\text { 4= Follow More than one Generally accepted guidelines are } \\
\text { followed as (GRI, UNGC, AA1000, ISO 26000) }\end{array}$ & \\
\hline \multirow[t]{5}{*}{ RL2 } & \multirow{5}{*}{$\begin{array}{l}\text { To what extent does } \\
\text { the bank analyse and } \\
\text { disclose the } \\
\text { implications of the } \\
\text { change in CSR } \\
\text { policies and strategy } \\
\text { between the reporting } \\
\text { periods after periodic } \\
\text { examination? (change } \\
\text { in the scope, report } \\
\text { design, and the used } \\
\text { indicators) }\end{array}$} & $0=$ No disclosure & \multirow[t]{5}{*}{ GRI, 2013} \\
\hline & & 1=Little disclosure (small paragraph) & \\
\hline & & $2=$ Few disclosure (more than a paragraph) & \\
\hline & & $3=$ Apart of a section in the report (subsection) & \\
\hline & & $4=$ Full disclosure (a separate part of the report) & \\
\hline
\end{tabular}

